8

\title{
SOCIALIST URBANIZATION THROUGH STANDARDIZATION
}

\begin{abstract}
The whole area was broken into functional zones, which, in their turn, were divided into thirty-six residential complexes. Each one of these complexes was composed of residential buildings and primary service buildings—schools, kindergartens and nurseries, clubs, canteens, and sports facilities ... The design considered the construction experience from the residential area at the Stalingrad Tractor Factory and the Magnitogorsk Metallurgic Plant, where analogous complexes were calculated to hold 2,500 people.
\end{abstract}

The proposal at that time, on the development side, can be characterized as a kind of qualitative leap to a new kind of socialist city building. Despite the individual limitations of our project, practically all ideas and even aspects of the terminology became realized in contemporary architecture and city building.

-P. E. SHPARA (1998)

The Kharkiv Tractor Factory was an improvement on its Stalingrad predecessor in many ways, but none more so than in the residential sphere. Despite the fact that the Vesnin brothers had devised a general plan for the Stalingrad Tractor Factory sotsgorod in 1929, only half of that factory's workers were housed by 1931. The rest camped out on the plateau overlooking the factory or traveled to work on the crowded tram and bus lines from the city center of Stalingrad, about fifteen kilometers away. ${ }^{1}$ Archival photographs show rows of pitched white tents on the Stalingrad site that recall those used to house workers at Magnitogorsk.

New Kharkiv, the exemplary sotsgorod designed and built for the Kharkiv Tractor Factory, by contrast, proved that the lessons of architectural standardization for industry could trickle down to Soviet housing. As for industry, standardization 
of residential design was a primary strategy for meeting the first Five-Year Plan's capital construction goals because time did not allow for design variance. At New Kharkiv, residential and sociocultural buildings organized in replicable blocks introduced a sotsgorod model that improved on previous attempts in Stalingrad and Magnitogorsk, such that it became exportable to other Soviet industrial sites.

Standardization was a central preoccupation of Soviet architects, economic planners, and government officials during the first Five-Year Plan, although for each of those groups the reasons for pursuing architectural standards sprung from differing concerns. For Soviet architects, to embrace standardization was to embrace rationality, new technology, and to assist in the construction of environments appropriate to the novyi byt (the new socialist way of life). Soviet economic planners' embrace of standardization was a matter of self-preservation in a society hell-bent on rapid industrialization, since the tempo of the plan accelerated project delivery. For government officials, first Five-Year Plan was a colonizing project-its elemental goal was to plot dots on the map and connect them into a productive web. Standardization was a way to speed up construction, ensure a degree of quality, and to conquer, through installation of industrial complexes continent-wide, the otherwise uncontrollable vastness of Soviet space.

Although the Kharkiv Tractor Factory design team (Traktorstroi) and New Kharkiv design teams worked primarily in their dashed boxes-factory to the north, sotsgorod to the south-the projects were integrally connected (figure 8.1).

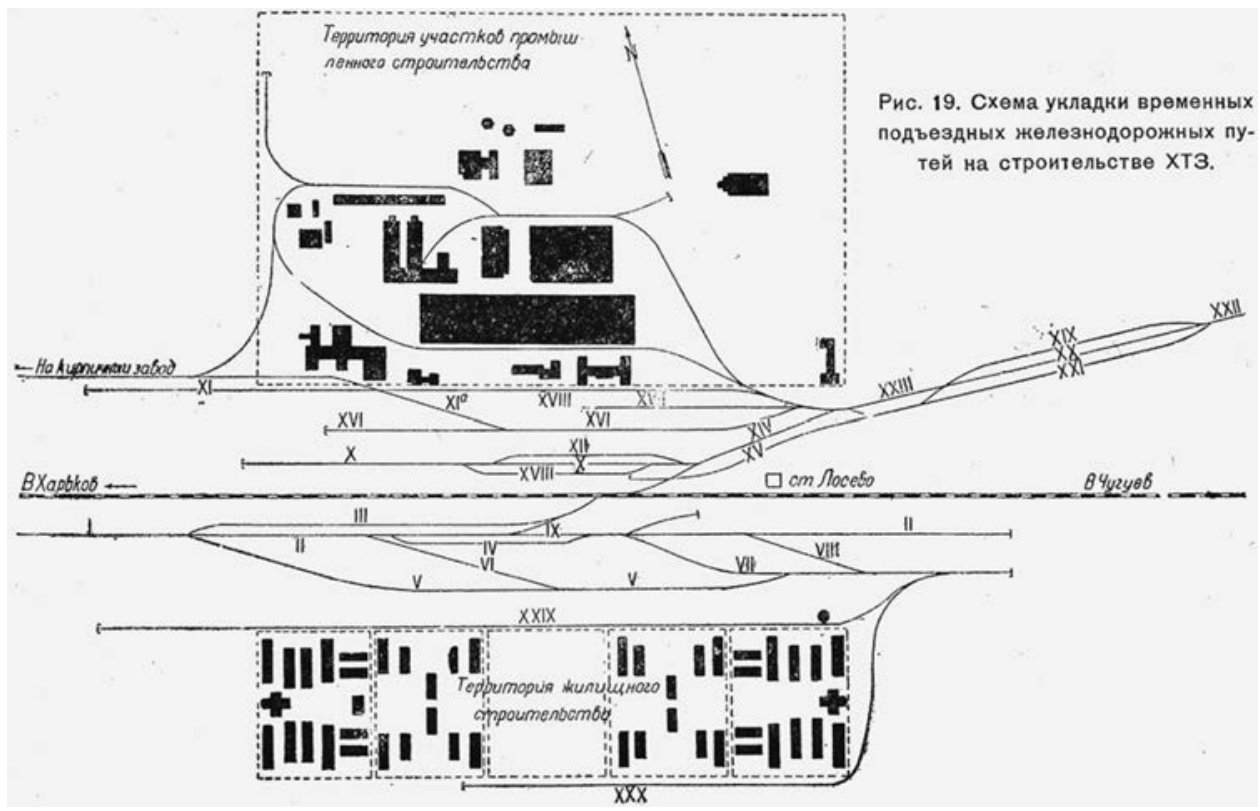

Figure 8.1. The separation of the tractor factory complex (top) and New Kharkiv sotsgorod (below) is stressed by individual dashed boxes around each project. The tram line that divides them leads into the city of Kharkiv to the west. N. Baltuzevich, Opyt i uroki stroitel'stva KhTZ (Moscow: Gosstroiizdat, 1932), 34. 
Traktorstroi design engineers and New Kharkiv architects, the latter under the leadership of architect Pavel Aleshin, collaborated to ensure that their projects came online more or less simultaneously. Like Baku, Kharkiv offers a prime example of socialist urban praxis, although Aleshin was under more pressure than Ivanitskii had been in Baku to solve pragmatic problems quickly within a mercurial theoretical and political context. The socialist settlement debate was at its height during the same months in which the New Kharkiv sotsgorod architectural brief was being drafted. Aleshin noted that it was an "unnerving" time to be designing the very type of project that resisted clear definition. ${ }^{2}$

The ideological fog that surrounded the proper form for the sotsgorod unsettled the designers, but it was not the most distressing circumstance that they had to reckon with. In the immediate vicinity of the site, farming communities were being forcibly collectivized in a state-peasant struggle so violent that Lynne Viola has characterized it as a second civil war. ${ }^{3}$ The early months of 1930 , when the design team was frantically devising plans, were particularly brutal. De-kulakization (the stripping of property from wealthy peasants) was in full swing - twelve kulak farms were attacked and looted in one village near Kharkiv in a single outing. ${ }^{4}$ On one March day in 1930, mass uprisings were reported in sixteen districts of Ukraine, with peasant groups of up to 500 people facing off against Soviet collectivizers with sawn-off shotguns, hunting rifles, and axes. ${ }^{5}$ These episodes do not figure in the histories of the Kharkiv Tractor Factory written by Soviet authors, nor do they show up in archival materials related to the project, but they must undoubtedly have disquieted the designers in their work.

In Kharkiv, both the tractor factory and sotsgorod were priviazki (architectural adjustments), variations on architectural themes explored first elsewhere. Out of the spotlight, with comparatively low expectations compared to Magnitorgosk, the designers of New Kharkiv had the freedom to experiment with ideas explored in the 1929 Gosplan conference and journalistic debates, competition briefs, and designs for other sites. On this less prominent site, urban and architectural ideas floated for Magnitogorsk finally materialized.

\section{Establishment of Socialist Housing Types}

At the beginning of 1927, the architect Georgii Vegman focused on the critical relationship between the Soviet housing crisis and typological design in an essay published in Sovremennaia arkhitektura (SA). ${ }^{6}$ The only way to improve the abysmal per capita living area allotted to each Soviet citizen, and solve the housing problem that was negatively impacting Soviet industrial growth, was to devise rational, replicable unit and building types, he argued. "The consolidation and concentration of construction organizations, and the establishment of types, are the essential prerequisites to reduce the cost of construction," Vegman insisted. ${ }^{7}$ In direct response 
to his plea, SA launched the "Comradely Competition for Communal Housing" in late 1927 to brainstorm new standardized residential units within the socialist framework. ${ }^{8}$ The eight published competition entries promoted the entire residential complex not as simply an agglomeration of individual units, but as a "social condenser," a collective space in which new social relations could be inculcated. At the same time, the entries capitalized on the designers' control of space, specifically the phenomenological asset of sectional generosity (expanded ceiling height) within the tiny footprint of the individual living cell. The promise of the competition entry designs prompted Stroikom RSFSR (the Building Committee of the Russian Republic) to tap the architect and SA editor Moisei Ginzburg to head a new Typification Section (Sektsiia tipizatsii) in 1928, to design experimental housing types, establish standards for future development, and draw up programs for the training and qualification of technical personnel. ${ }^{9}$

Over the next few months, the Stroikom Typification Section designed six standard residential unit types. When these units were first published in SA in early 1929, Ginzburg laid out an exhaustive list of social and technical criteria that the section's architects considered as they designed. ${ }^{10}$ "The constructive study of housing should be based on the principle of maximum standardization of all elements, and should strive for the industrialization of building," Ginzburg insisted, meaning that Soviet architects engaged in housing design were beholden to use mass-produced elements to mass produce housing. But on a broader conceptual level, Ginzburg encouraged architects to think of standardization as a multiscalar design problem. "The design solution for the residential cell," he explained, "leads to the solution for the residential block and residential area."11

The most innovative unit designed by the Stroikom Typification Section, the Type F, successfully met the laundry list of criteria Ginzburg laid out (figures 8.2 and 8.3). The one-room twenty-seven-square-meter unit is accessed up or down a half flight of stairs from a skip-stop common corridor. The high-ceilinged living space, naturally lit by a wall of windows, was designed with only a "kitchen element"-a closet with shelves for dishes and a hotplate-to save space and encourage the occupant to dine in the communal canteen. Sleeping occurs in a low-ceilinged loft six steps up or down from the living space (squeezed above/below the skip-stop corridor) that serves as a secondary source of light and air from windows on the back wall of the building. Despite the significant press they received, however, only six projects that utilized Stroikom units were built, the most notable being the Narkomfin Communal House in Moscow, completed in 1929.12

Tsekombank, the Central Bank of Communal Services and Housing and the primary state construction funder, undertook its own housing typology research, yet it forwarded a more flexible procedure for housing standardization that encouraged local modification. From 1924 to 1928, Tsekombank gathered "a huge and diverse collection of materials, from almost all regions and districts of the Union." The bank published the materials in the album Projects for Workers' Dwellings 

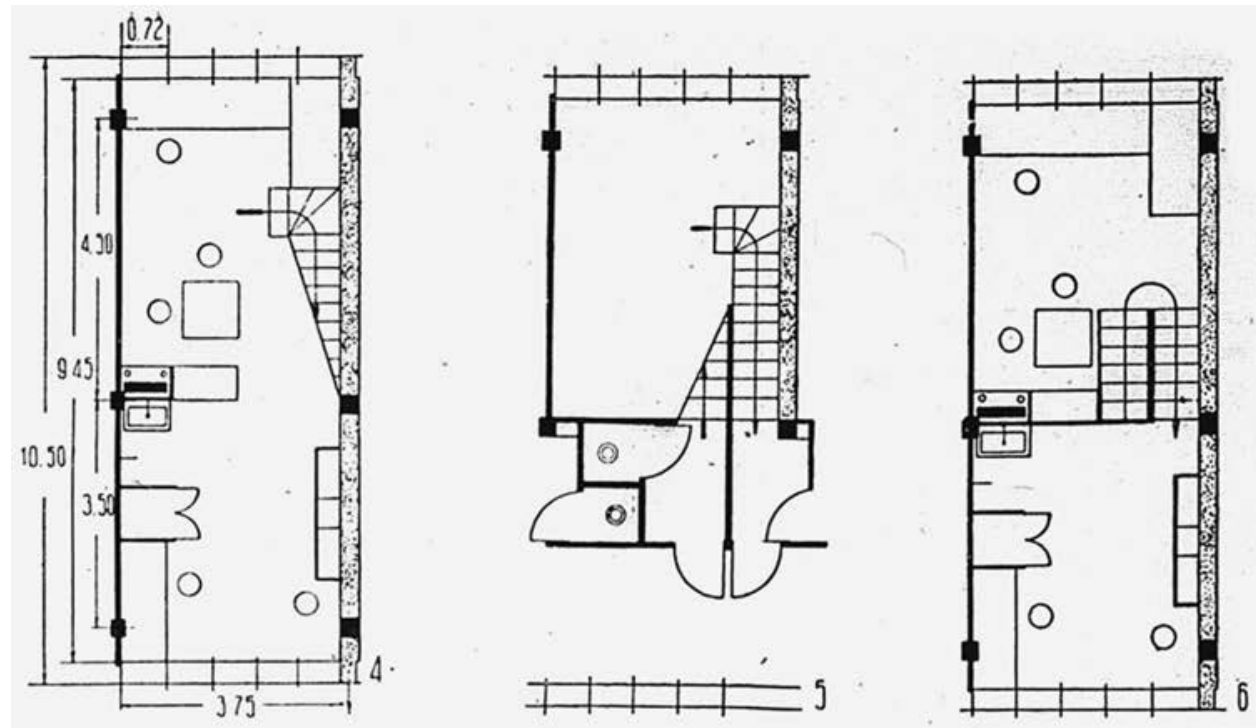

129. 2-й дом СНК. Планы квартиры-типа F. 4-й, 5-й и 6-й этажи
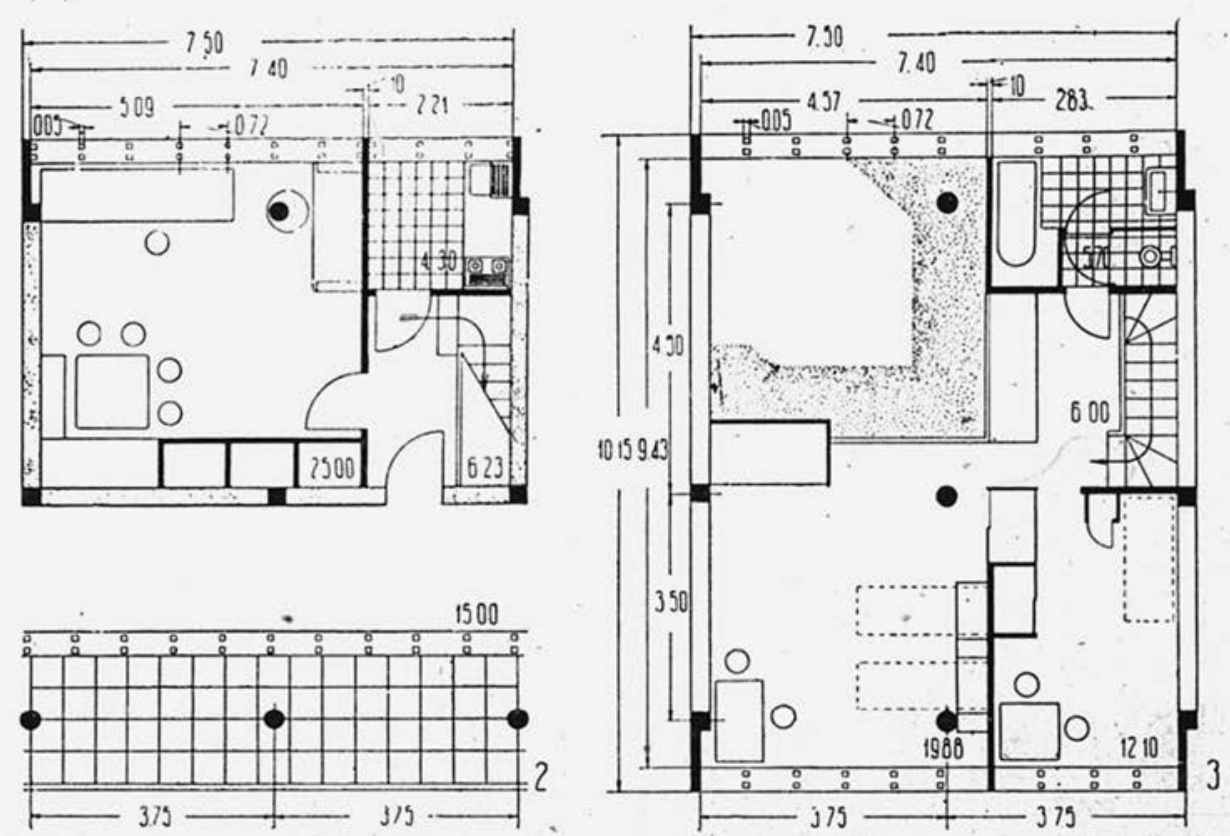

130. 2-й дом СНК. Планы квартиры-тип Н. 2-й 3-й этажи. М. Я. Г и н з бур г и И. Ф. М и ли ни с

Figure 8.2. Narkomfin F-type unit (top) and K-type unit (bottom) based on research by the Stroikom Typification Section. Architects: M. Ia. Ginzburg and I. F. Milinis. M. Ia. Ginzburg, Zhilishche (Moscow: Gosstroiizdat, 1934), 105. 

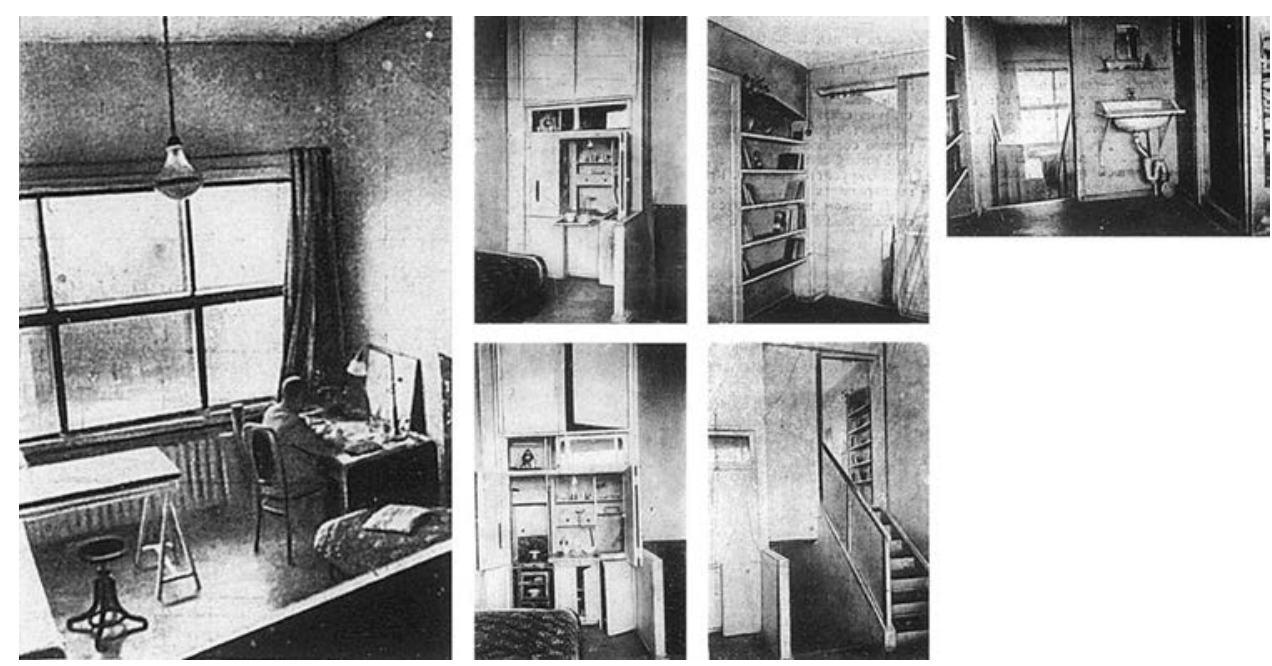

Figure 8.3. F-unit interiors, RZhSKT House, Saratov, Russia, 1930. Architect: S. A. Lisagor. M. Ia. Ginzburg, Zhilishche (Moscow: Gosstroiizdat, 1934), 127, 129.

(Proekty rabochikh zhilishch) that "summarized the accumulated experience and reflected existing achievements in the design of housing." The album, published in 1929, gestures at the practice of priviazka, though the text uses different terminology, including the term popravka (amendment) and mestnyi programmnyi korrektiv (local programmatic adjustment). ${ }^{13}$

E. Luganovskii, director of Tsekombank, noted in the album's preface that "given the extremely varied living and climatic conditions in each region of the USSR, it is obviously impossible to produce comprehensive solutions immediately." ${ }^{4}$ The editors of the album also highlighted the Soviet Union's environmental heterogeneity, which precluded rigid typological replication:

The variety of local conditions in both the center and on the edges of our Union make it impossible to identify a single solution to the housing question through developing type-projects. To produce the massive number of required types to meet all local requirements, considering all extremely diverse climatic, domestic, and technical conditions, would be an overly long and overwhelming task for a single publication. [We decided] that a more productive and urgent task was to publish only the technical, economic, and sanitary fundamentals of housing design, expressed through concrete examples, to provide a solid basis for local study and detailing ... Changes in the building plot, orientation of the house, its number of stories, even the living area for specific units are achieved by minor amendments (dostigaiutsia neznachitel'nymi popravkami) to the original project or by choosing from several typical options. ${ }^{15}$

Most of the texts in Tsekombank's Projects for Workers' Dwellings, like the above, encourage architects to modify the types in the pages. The Tsekombank units are middle ground hybrids between type, which asks to be replicated near exactly, and 
model, which is a diagram that can absorb design changes. Although the designer is wise to start from a proven housing type, the editors note, nearly all unit characteristics are available for "minor amendments," including the building's solar orientation, its height, and the area of each unit. It is even possible to cherry-pick various typological options and create a new building form that is nonetheless related to the originals from which it was developed. This flexible process of architectural accommodation to a given context-the very definition of priviazka-does not map onto a Western conception of standardization but is logical given the diverse conditions for which Soviet architects were likely to be designing.

The Tsekombank album separates the types into four divisions: urban housing, rural housing, collective living buildings, and service buildings. The urban types are designed by section (sektsiia), a repeatable block of units that share stairwell access. The section, which might hold anywhere from two to four units, is repeated horizontally and stacked vertically until the desired site is filled or population met (figure 8.4). Rural types in the album include "paired" single-story houses like those built at Stepan Razin in Baku, and even wooden barracks like those occupied by Magnitogorsk's workers. The collective living types, like the dormitory seen in the illustration, are composed of individual sleeping cells supplemented by shared programs like canteens and reading rooms.

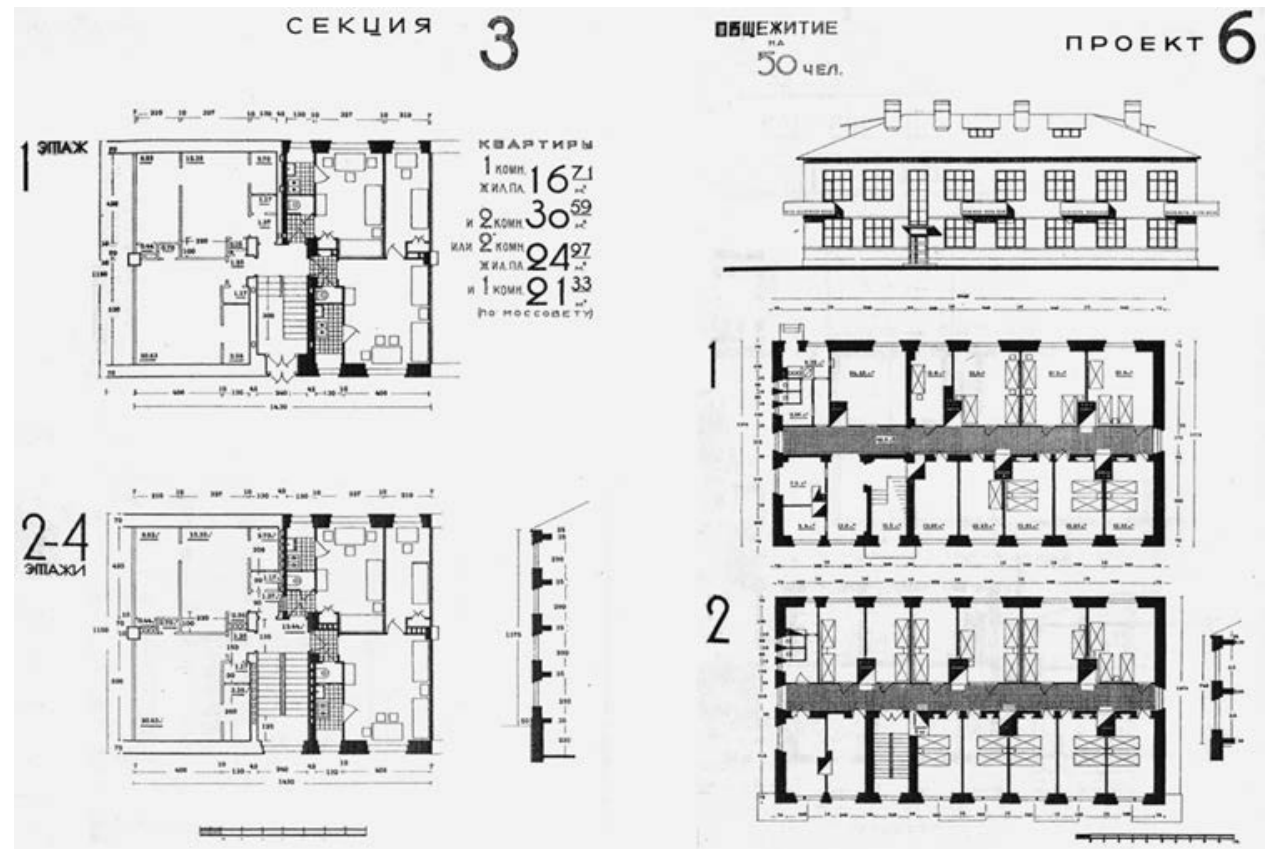

Figure 8.4. Worker housing types from Tsekombank, Projects for Workers' Dwellings. The multiunit apartment "section" (left) is a repeatable block of units that share stairwell access. The dormitory-style building (right) is composed of individual sleeping rooms and communal facilities. Tsentral'nyi bank kommunal'nogo khozaistva i zhilishchnogo stroitel'stva, Proekty rabochikh zhilishch (Moscow: Izdanie Tsekombanka, 1929), 27, 195. 
Though these initiatives engaged typology at the discrete scale of the living cell and residential building, standardization of larger urban types and models-the entire factory complex, the neighborhood, the city-did not emerge until well into the first Five-Year Plan's crisis of manufactured deadlines. After the socialist settlement debate had died down, the Stroikom Typification Section was transformed into the Socialist Settlement Section of the Gosplan Building Division of the Russian Republic (Sektsiia sotsrasseleniia stroisektora gosplana RSFSR). ${ }^{16}$ Among the experts working on new standardized settlement units were the architects Mikhail Barshch, Moisei Ginzburg, and Ivan Leonidov; sociologist Mikhail Okhitovich; and economist Genrikh Puzis. The Socialist Settlement Section's disurbanized, a-centralized, decentralized, and dispersed settlement diagrams skipped over the intermediate scale of the site plan, and instead jumped directly to the regional implications of disurbanization (figure 8.5). The dispersive process is clear in these diagrams, but the form of any given node is not.
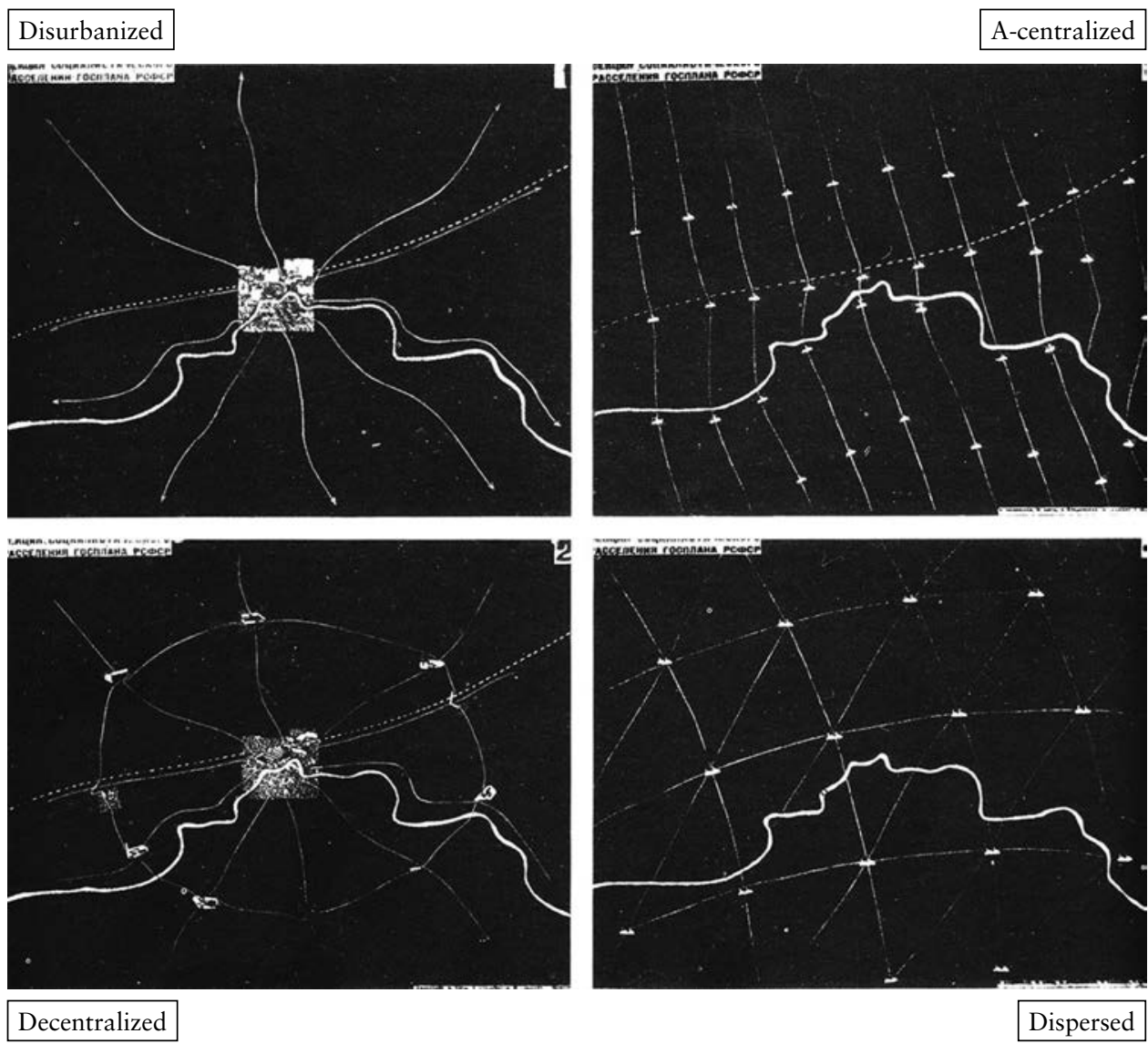

Decentralized

Figure 8.5. Socialist settlement schemes: disurbanized, a-centralized, decentralized, and dispersed settlement, 1930. Designers: Socialist Settlement Section of Gosplan RSFSR. Diagram by the author based on Sovremennaia arkhitektura, no. 6 (1930): 2. 
Replicable urban units perform at the middle scale-what we now call urban design-where architecture and particularities of the site remain material and legible. This middle scale was where the New Kharkiv sotsgorod team workedparticularly with the design of the typical zhilkombinat (housing combine), the planned, standardized residential block that includes housing, educational institutions, social and commercial services, and local commercial programming for a population of 2,000-3,000, the building block of the sotsgorod.

Just as the tractor factory design team had learned from the mistakes at Stalingrad, the New Kharkiv team benefitted from housing research and development that preceded it in Moscow, Magnitogorsk, and elsewhere in the Soviet Union. Architectural and site planning criteria written into the Magnitogorsk competition brief, and well known to the head architect Pavel Aleshin, can be discerned at New Kharkiv, as can Stroikom Typification Section housing design criteria, and the Tsekombank housing type designs.

\section{Actionable Sotsgorod Brief}

Less than a month after Losevo was chosen as the Kharkiv Tractor Factory site, Traktorstroi, the entity overseeing project delivery, collaborated with the design-consulting arm of the Ukrainian branch of the People's Commissariat for Internal Affairs (NKVD) to divvy up and complete preliminary civil engineering tasks. ${ }^{17}$ Local specialists prepared site-specific materials including two geological soil sections, a detailed site plan showing possible water supplies to the site, a "wind rose" diagram, and a topographical site plan (figure 8.6). The blueprints confirmed the Losevo site's assets; it was connected to heavy rail, was flat and on a solid geological base with good access to water, and had a regular wind profile. Logistics planning to ensure the timely arrival of building materials and workers to the site was also mobilized as part of this predesign effort.

In February 1930-after the publication of the Magnitogorsk All-Union competition brief, but before the publication of its entries-the NKVD Section for Rationalization, Standardization, and Reconstruction of the Communal Economy of the Ukrainian Republic, under which the New Kharkiv design team sat, submitted an initial sotsgorod brief. ${ }^{18}$ It defined New Kharkiv as a "transitional" model socialist settlement, with three programmatic sectors-production, residential, and social-cultural-that together would support a novyi byt:

The function of the production sector is to create real value for the livelihood of the workers. The function of the residential sector, influenced by centuries of tradition, is to serve workers' individual existence, their physical and biological needs, and to maintain their strength and health for human procreation, introspection, and education. All problems of byt are resolved 
in this residential sector, making it more stable and causing its extraordinary transformation and consolidation. It is precisely here that the most painless and quick transition to complete socialization lies. The function of the sociocultural sector, in direct connection with the residential sector, is to improve relationships between workers, and to develop a societal organization that serves the needs of the team. ${ }^{19}$

The New Kharkiv sotsgorod brief was more tempered in its approach to socialization than the Magnitogorsk competition brief had been, a fact that can be attributed to its precise temporal situation and obligation to buildability. By February 1930, the tide was turning against rapid, enforced socialization. Even Sabsovich was modifying his language, writing that "the definition of the socialist byt is far from being sufficiently developed ... we do not yet have any experience in this matter. We have to feel and fumble in the dark to shape this new life. With that in mind, it is necessary to remember that while we build our cities, we are in a period transitioning towards socialism." ${ }^{20}$ Although the Central Committee of the Communist Party had yet to issue its "Resolution on the work to restructure byt," which shut down "semi-fantastic" schemes like Sabsovich's, bureaucratic support was waning for radical cultural revolution because industrial demands eclipsed ideological imperatives as the first Five-Year Plan pushed into its second half. ${ }^{21}$

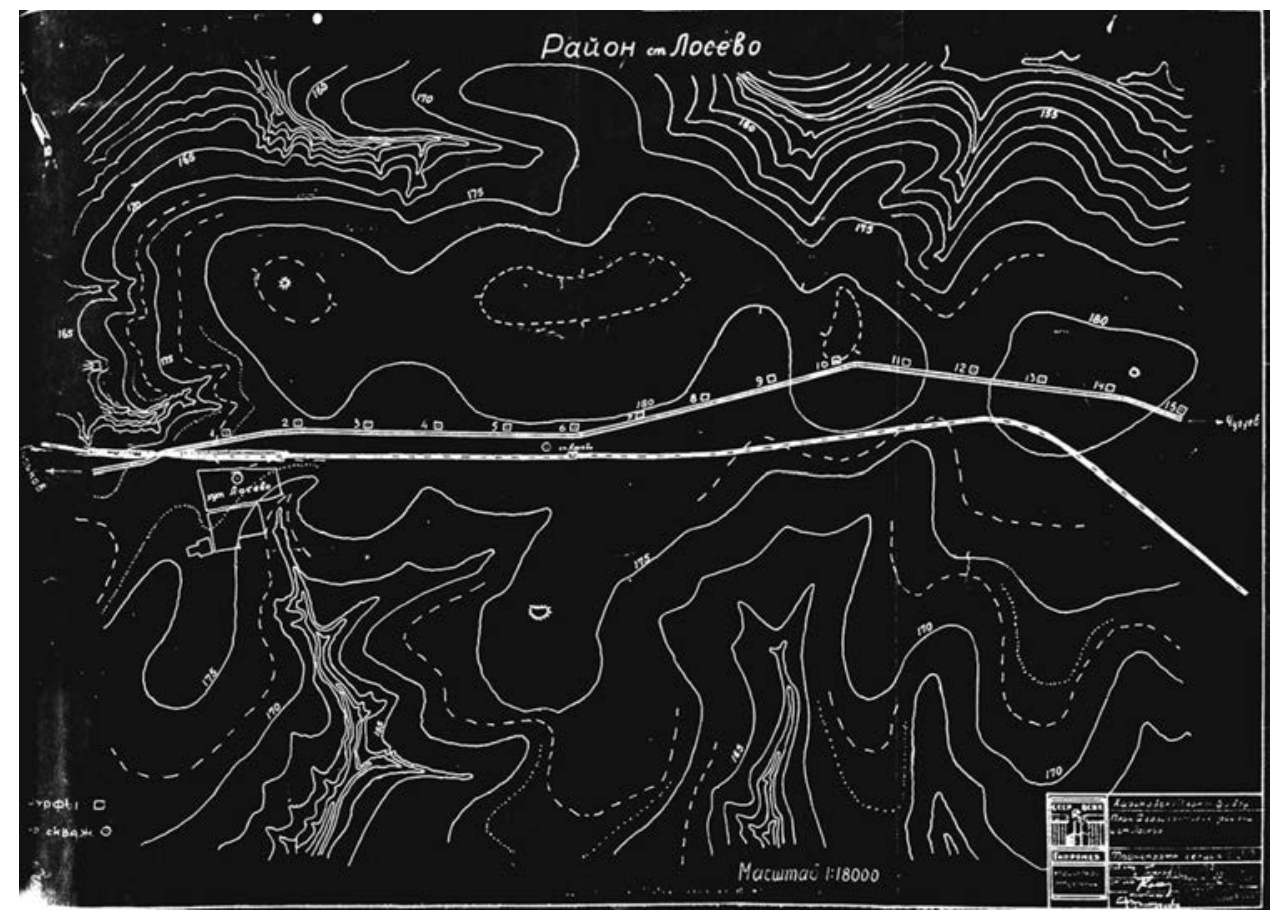

Figure 8.6. Topography at the Losevo site, chosen for the Kharkiv Tractor Factory, 1929. Report authors: Ukrgipromez. TsDAMLM Ukrainy, f. 8, po. 1, od. zb. 259, ark. 33. 
The language of the New Kharkiv architectural brief registers its liminal status. Naming the project a "transitional socialist city" left the door open for the inclusion of certain traditional (i.e., prerevolutionary) architectural forms and cultural practices. The brief took a moderate stance on the controversial issue of familial structure, for instance, stipulating that "child-rearing will transition to become entirely socialized, such that children up to seventeen years of age will all be under socialized care in the near future . . preschool and school-aged children up to ten years old will live with their parents with the exception of the daytime." 22 The New Kharkiv brief was, however, also laced with reference to a new socialist byt that would be constructed through interdependence of productive, residential, and sociocultural spheres.

The socialization of byt language in the New Kharkiv brief may well have been mandated by economic policy. In late 1929, the state banking system established strict borrowing preconditions for housing projects that were pegged to social transformation. In a Sovnarkom resolution attached to the New Kharkiv brief, Tsekombank requirements for residential construction lending in the 1929-30 building season are spelled out. "In the case of projects submitted by the borrower for house-communes, block developments, and villages, lending will be extended only to those that involve the following elements for the socialization of life: communal kitchens and dining / eliminating the kitchen in the individual apartments / nurseries, kindergartens with daycare for children, mechanized laundries, sports grounds and club facilities." 23 To receive capital funding for a housing project from Tsekombank, the borrower had no choice but to include robust communal services for the residents and refrain from including kitchens in the majority of the living units. But while this policy of Tsekombank's seems to have predetermined the constituent programs for New Kharkiv, the design of the site plan and buildings was a matter left to the New Kharkiv team. This process aligned with the bank's philosophy, which stated that typical plans "absolutely require local programmatic adjustments (korrektivy)." 24

\section{Linear City}

Late 1929 to mid-1930, when the first site plans for New Kharkiv were being devised, was the most active period of the socialist settlement debate. Among the theoretical tracts published in just this small window of time were Toward the Problem of Constructing the Socialist City (Gosplan), Sotsgorod (Miliutin), Cities of the Future and Socialist Cities (Sabsovich), and the Magnitogorsk AllUnion competition brief. All of these texts, and the vigorous public discussions that accompanied them, established the intellectual foundations for socialist space. More often than not, the authors sidestepped formal recommendations and 
stopped well short of nuts-and-bolts design detail. Stalingrad, Nizhnii Novgorod, Kharkiv, and a handful of other industrial settlements constructed during the first Five-Year Plan were the testing grounds.

The architect Pavel Aleshin was the head of the New Kharkiv design team. At that time, Aleshin was the chief architect of Giprograd, the State Institute for City Planning in the Ukrainian Republic, and at forty-nine an exact contemporary of Aleksandr Ivanitskii. Both architects were born in present-day Ukraine in 1881, attended the prestigious Institute of Civil Engineers in St. Petersburg, and graduated together in 1904. ${ }^{25}$ Like Ivanitskii, Aleshin studied under notable Russian civil engineers at the institute, and he worked with one, G. D. Dubelir (author of the seminal book City Planning (Planirovka gorodov) from 1911), as chief city architect on a plan for Murmansk in 1918. Aleshin conducted the majority of his professional life in prerevolutionary and then Soviet Ukraine, but maintained contacts in Leningrad and Moscow, and kept abreast of architectural debates ongoing in the Soviet capital. Books from Aleshin's professional library that now reside at the Canadian Centre for Architecture include copiously annotated texts from the 1929-30 socialist urbanism debates. Aleshin's personal papers at the Central State Archives and Museum of Literature and Art of Ukraine (TsDAMLM), are also stocked with evidence of his engagement with socialist settlement issues. An original copy of the Magnitogorsk competition brief is clipped together with photographs of competition drawings and models, and materials from the Stalingrad sotsgorod competition are tucked in an envelope and annotated on the verso in Aleshin's hand, even though he did not enter either competition. ${ }^{26}$

In Aleshin's personal copy of the November 1929 Gosplan conference proceedings, the opening paper by architect A. Zelenko received the most readerly attention. ${ }^{27}$ In it, Zelenko proposed a linear model for socialist settlement, and the passages that explain and justify this proposal are those most vigorously highlighted by Aleshin. The new socialist city, stated Zelenko, should be "built on the principles of production, expanded in a linear direction." ${ }^{28}$ Zelenko described three zones in the linear city-manufacturing, green space, and residentialand articulated their relationships. "The manufacturing part of the city," he wrote, "should be separated from the residential area by a green boulevard or band on which internal transportation runs, and this is where the residential sector begins." The width of this green band is to provide a substantial buffer between the factory and housing but also be narrow enough to provide workers a walking commute. Zelenko continued, "the houses, which will accommodate 2,000-3,000 residents, can be called a block (blok), or a zhilkombinat. These residential blocks, separated from one another by a large green reserve and roads, can be placed in a chessboard grid, so that the whole city of 50,000 residents occupies 5-6 kilometers in length and 2-3 kilometers in width." ${ }^{29}$ Zelenko included with his text diagrams of the linear organization of the industrial sector 
(diagram 1), and a single residential block bundled with nurseries and kindergartens (diagram 2) (figure 8.7).

Zelenko's ideas were foundational for the organization of the Kharkiv Tractor Factory and New Kharkiv. New Kharkiv's site plan, however, bears little resemblance to Zelenko's diagrams, and instead mimics the linear city proposed by Nikolai Miliutin for the Stalingrad Tractor Factory (figure 8.8). ${ }^{30}$ Like Zelenko, Miliutin stressed that new socialist settlements must be organized according to industrial principles. "A flowing functional-assembly-line system is an absolutely necessary basis for the new planning," Miliutin wrote. "The residential sector of the settlement must be set up parallel to the productive zone and must be separated from it by a green belt (buffer zone). This protective strip must be no less than 500 meters wide." ${ }^{31}$ Miliutin detailed more thoroughly than Zelenko the multiple social and economic benefits of a linear settlement scheme. First, the green strip acts as the "lungs" of the project to separate and filter any stray industrial particulates that might drift toward the residential zone. Second, the relative proximity between the factory and its sotsgorod cuts out the "superfluous expense for intersettlement transportation," since each worker has a short ten- to twenty-minute walk to work from his sleeping cell. Lastly, the green axis structures rational linear growth of the sectors in either direction along its length while maintaining the optimal distance between them.

Between Zelenko, Miliutin, Okhitovich, and others, the linear city concept was in the air at the start of 1930, when Aleshin and his team developed the first draft
A. training apparatus
Б. laboratory
B. auditorium + museum
$\Gamma$. storage
Д. assembly shops
E. manufacturing
C. raw materials
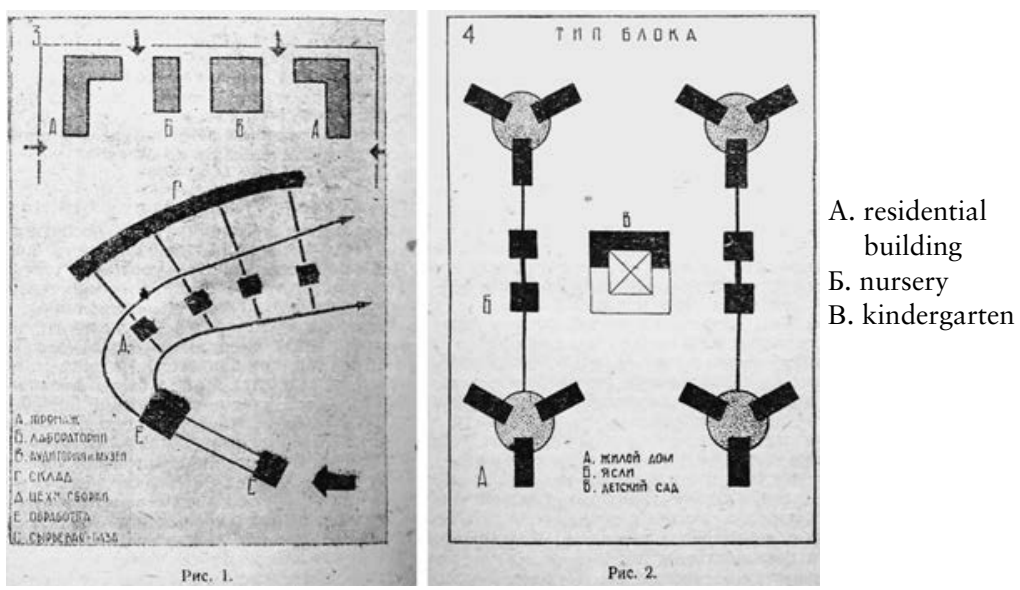

Figure 8.7. "Construction of Socialist Cities" diagrams. Diagram 1: linear organization of the industrial sector. Diagram 2: single combine-block residential cluster with common sociocultural amenities such as nurseries and kindergartens. A. U. Zelenko, "Stroitel'stvo sotsialisticheskikh gorodov," in K probleme stroitel'stva sotsialisticheskogo goroda, ed. Gosplan SSSR (Moscow: Izdatel'stvo "Planovoe Khoziastvo," 1930), 12, 15. 


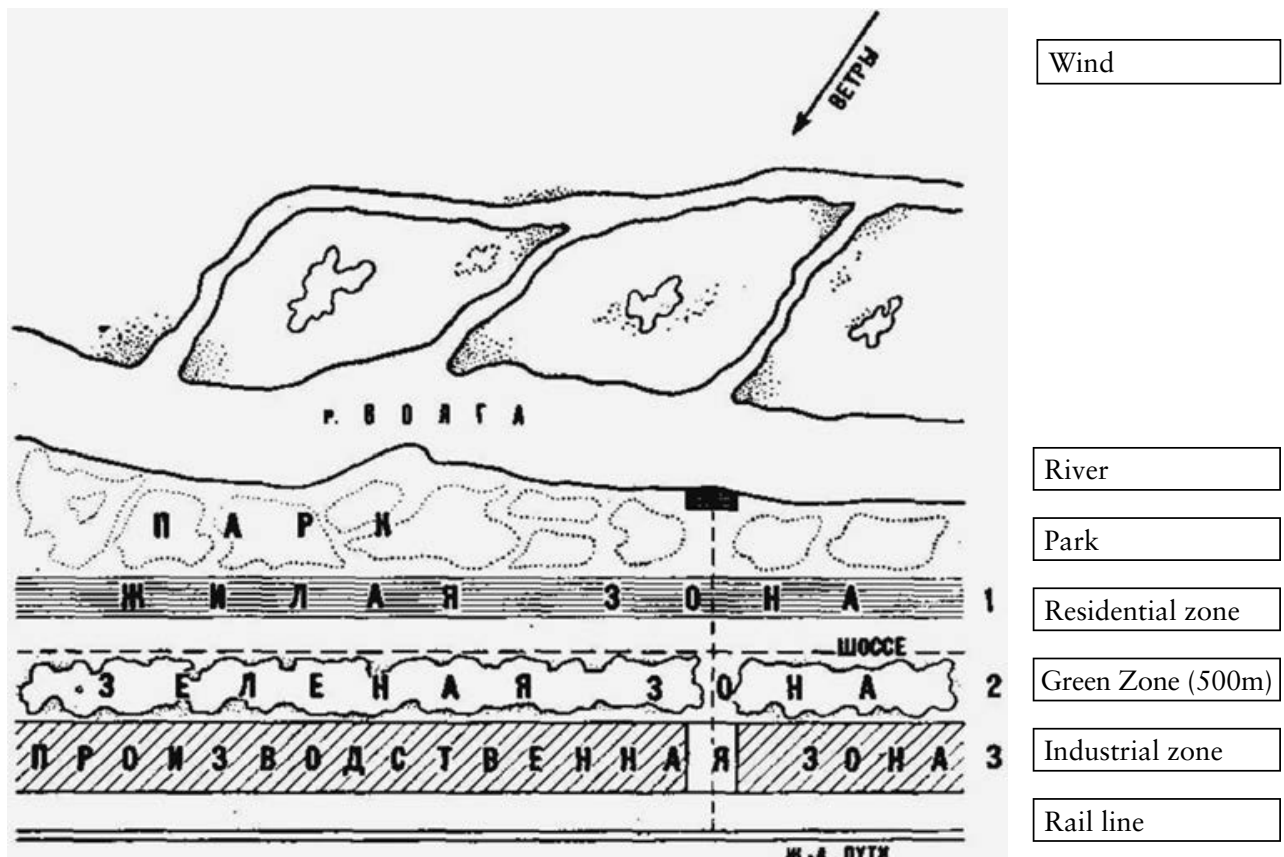

Figure 8.8. Linear city scheme for Stalingrad, Nikolai Miliutin, 1930. N. A. Miliutin, Sotstgorod: Problema stroitel'stva sotsialisticheskikh gorodov (Moscow: Gosudarstvennoe izdatel'stvo, 1930), 29. Diagram by the author.

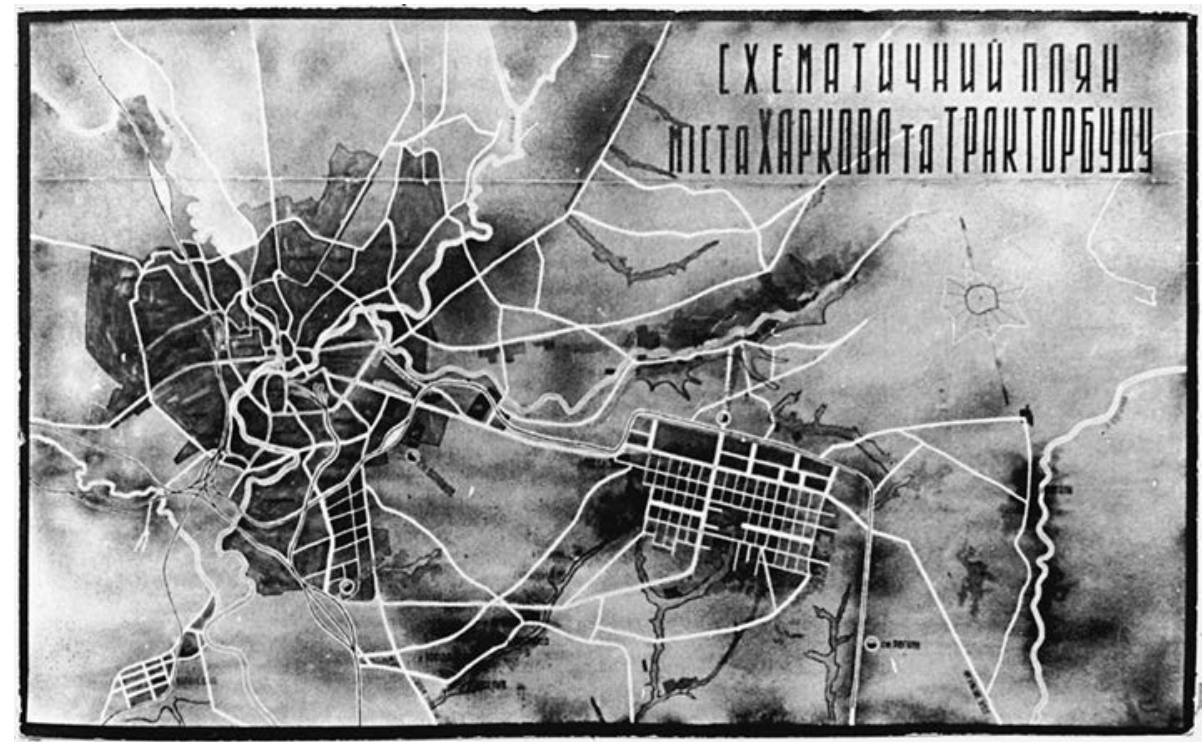

Figure 8.9. A schematic plan for the city of Kharkiv and its tractor factory, c. 1930s. The concentric prerevolutionary core of Kharkiv sits to the west, trailing a southeasterly transportation corridor on which a gridded urban rectangle, the future tractor factory and its sotsgorod, attaches. T. V. Tikhomirova, Plany i vidy goroda Khar'kova: zastroika istoricheskogo tsentra (Kharkiv: V.G. Korolenko State Scientific Library, 1989). 
designs for New Kharkiv. ${ }^{32}$ An early urban plan shows the concentric prerevolutionary core of Kharkiv to the west, trailing a southeasterly transportation corridor on which a gridded urban rectangle, the future tractor factory and its sotsgorod, attaches (figure 8.9). A concurrently drawn regional plan shows Kharkiv in the center, encircled by a corona of linear cities, though New Kharkiv would be the sole built example (figure 8.10).

A site plan and contemporary aerial photograph confirm that New Kharkiv was constructed with exactly the programmatic layering recommended by Miliutin (flipped 180-degrees from his diagram) (figure 8.11). The heavy rail line that

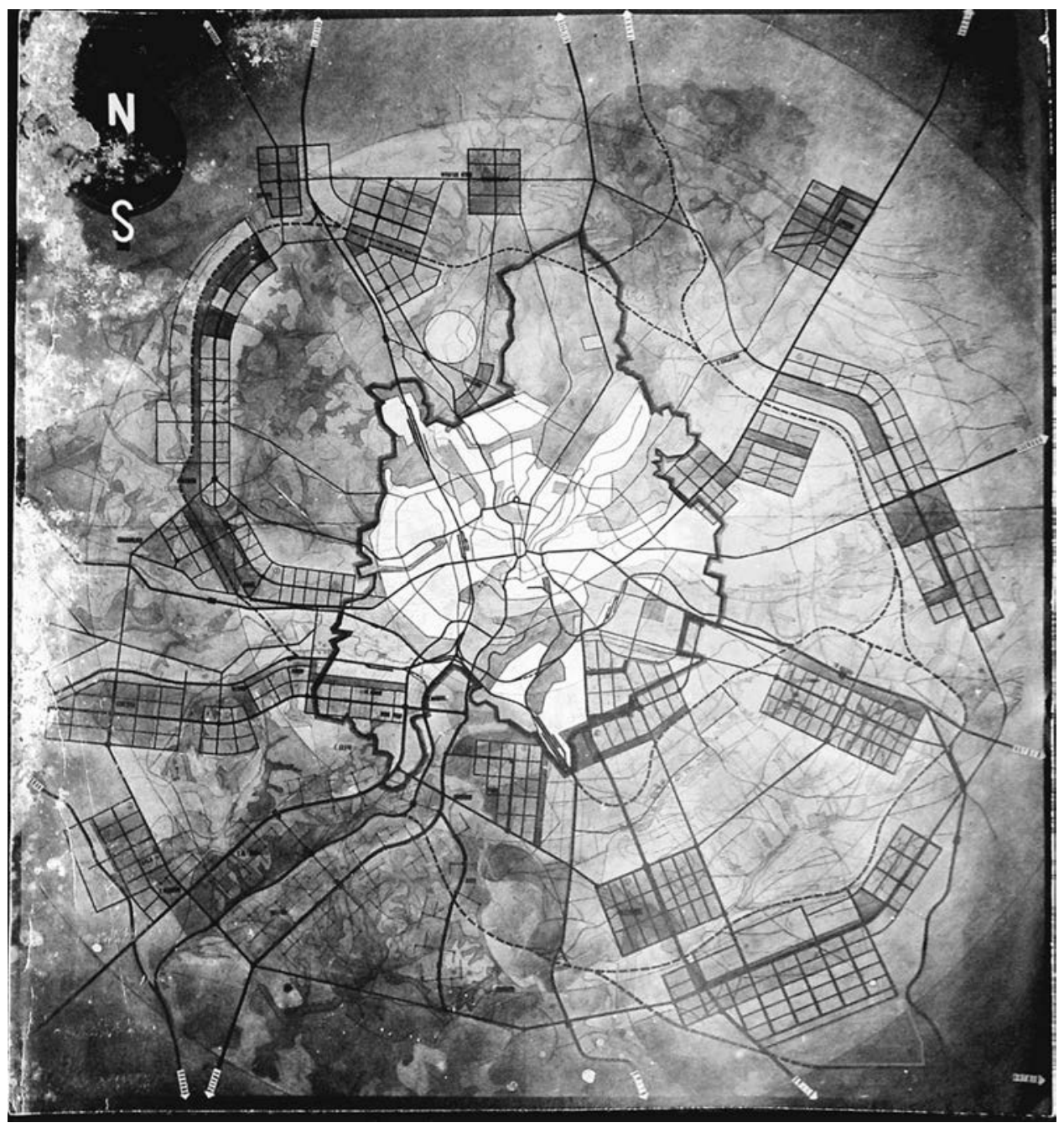

Figure 8.10. A schematic plan of linear cities. Kharkiv, Ukraine, 1929. This projective regional plan shows prerevolutionary Kharkiv in the center, encircled by a corona of linear cities, although New Kharkiv proved to be the sole built example. TsDAMLM Ukrainy, f. 8, po. 1, od. zb. 264, ark. 6. 

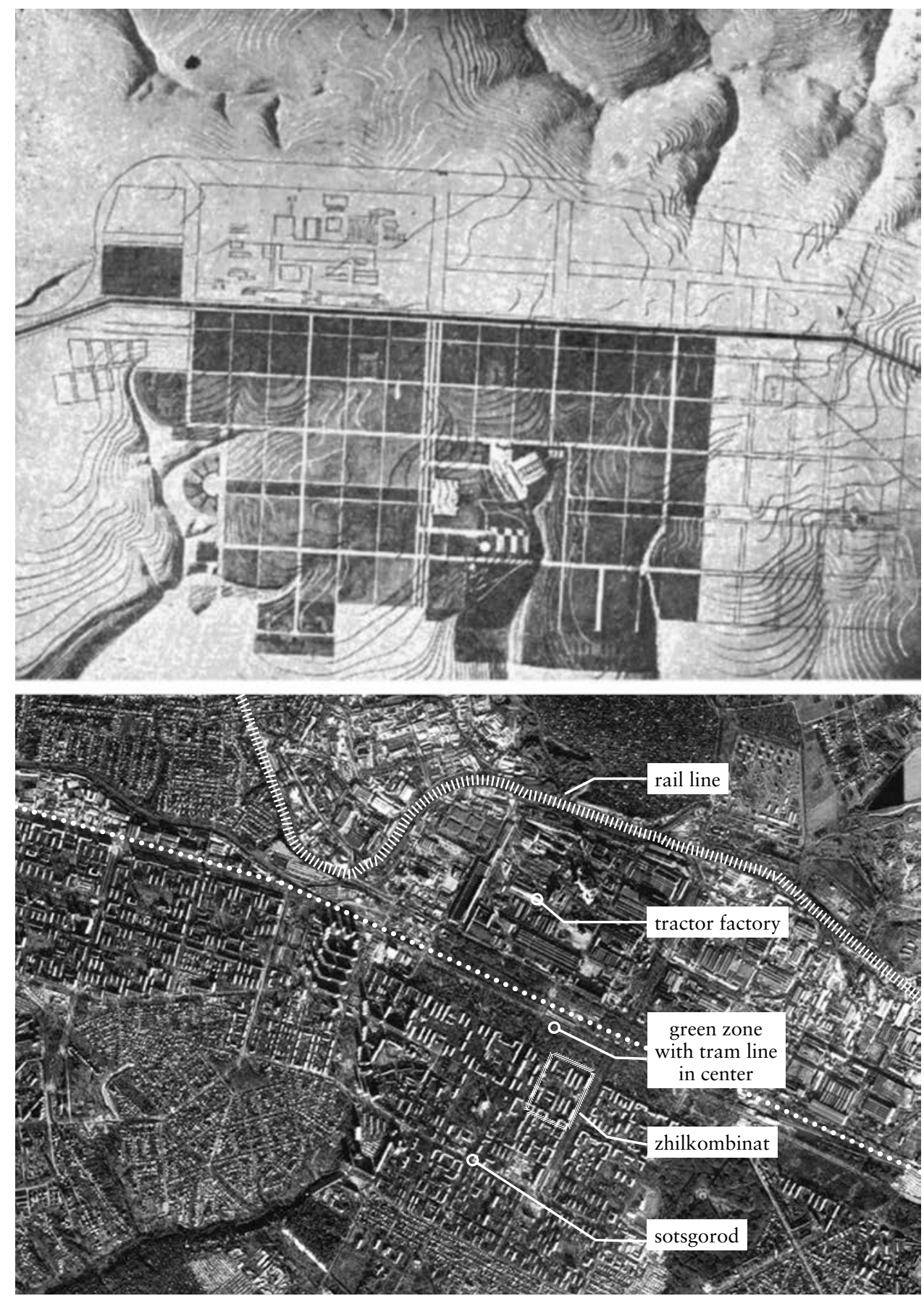

Figure 8.11. A linear city scheme for the Kharkiv Tractor Factory and the New Kharkiv sotsgorod (1930), and contemporary aerial photograph and diagram (2016). Note that the program layers at Kharkiv are $180^{\circ}$ from Miliutin's model. Plan from N. Baltuzevich, Opyt i uroki stroitel'stva KhTZ (Moscow: Gosstroiizdat, 1932), 23. Diagram by the author based on Google Earth aerial. 
connects Moscow to the Caucasus runs along the northeastern edge, below which lies the tractor factory precinct. Next, a green buffer-500 meters in width and carrying a tram line into the center of Kharkiv-separates the residential area of New Kharkiv from the factory zone. The diagram was built in Kharkiv, and the settlement structure remains unadulterated to this day, despite the fact that the interdependent relationship between the factory and residential area has been dissolved in the post-Soviet period.

The linear city model provided an additional logistical benefit in Kharkiv that was unarticulated by the theories of Zelenko or Miliutin but integral to meeting the fifteen-month construction deadline on an actual site. The green buffer was a construction expansion joint. The factory and sotsgorod projects could be built simultaneously but at different rates, sharing management, materials, and labor when convenient.

\section{Demographically Closed System}

Before an architectural scheme could be devised for New Kharkiv, Aleshin and his Giprograd colleagues needed the settlement's projected population subdivided by age, gender, and family structure to set the balance of residential unit types within the project. The tractor factory project's earliest demographic charts propose a final target population of 36,287 . This emphatically precise number separates various demographic subgroups by livelihood including staff of the tractor factory; laborers at the factory; laborers in agriculture (to support the city); local and handicraft industry workers; commercial-sector employees (shop keepers, etc.); state catering employees; transportation workers; construction workers; employees of administrative organs; employees of municipal services; pensioners and nonworkers (bezrabotnye). ${ }^{33}$ Additional demographic tables disaggregate the population further, dividing raw numbers into gendered percentages and age groups (men would ideally account for two-thirds of the total population). For each age, from under a year through sixty and over, an optimal percentage of the total population is given, again subdivided by gender. As in the idealized projections in the Magnitogorsk competition brief, the key demographic groups of optimal working age for the Kharkiv Tractor Factory project account for 65-70 percent of the settlement population. In this first round of demographic data, the familial composition of the settlement is also projected, with singleton "families" of one composing the largest demographic group.

Demographic charts proliferated in early project briefs for New Kharkiv, yet they rarely aligned. The categories and percentages articulated in February did not match up with March's projections. Why the numbers kept shifting is unclear, but there was certainly administrative purpose to these projections. James C. Scott proposes that the "continually frustrated goal of the modern state is to reduce the chaotic, disorderly, constantly changing social reality beneath it to something more 
closely resembling the administrative grid of its observations." ${ }^{34}$ The State Institute for Metallurgical Factory Design in the Ukrainian Republic (UkrGipromez) and the Ukrainian NKVD, the de facto clients for the sotsgorod, desired for New Kharkiv to be a neatly closed system, "a terrain and a population with precisely those standardized characteristics that [would] be easiest to monitor, count, assess and manage." ${ }^{35}$ By setting such precise demographic targets for the sotsgorod and making sure that the architects designed to those targets, UkrGipromez hoped to chart into being a perfectly circumscribed population to run the factory complex. No more, no less, and no differently composed.

Members of the design team "worked over" the UkrGipromez charts with data provided by the Central Statistical Administration (Tsentral'noe statisticheskoe upravlenoe or TsSU) to arrive at statistics better aligned with the socially transformative charge of the sotsgorod. "The age composition of the workers must consider the conditions for the planned new byt," the designers insisted. ${ }^{36}$ Using a chart with revised demographic percentages, the designers homed in on spatial parameters for living units. They set areas for living cells (zhiliachiki) per familial group: a single person was allotted twelve square meters, a couple twenty square meters, and upward to the final six-person unit that was granted fifty-four square meters. ${ }^{37}$ The team used the TsSU data to set the final unit mix. Singletons made up 23 percent of the population, and their living cells represented the most prevalent unit type.

\section{The Architects Assemble}

Petr Efimovich Shpara was a twenty-seven-year-old recent architecture school graduate and former student of Aleshin's from the Architectural Institute in Kyiv when he was tapped to participate on the New Kharkiv design team. It was a plum job in a burgeoning city. "Life in Kharkiv, the capital, was in full swing (kipela)," Shpara wrote in his autobiography. "The city was successfully transforming and had become a large socialist center with the lively rhythm of powerful industry. Kharkiv amazed us young architects with its dizzying creative energy. We understood how lucky we were, what a high honor it was, to join such a big creative collective engaged in designing and building such an enormous residential area immediately after graduating from the institute." 38

By this time in 1930, Shpara, born in a rural village to two illiterate parents, had already rubbed shoulders with the brightest stars in the architectural firmament as part of the Ukrainian delegation to OSA's First All-Union Congress in Moscow in 1929. He and other young delegates "listened with excitement to the speeches of the famous Constructivists," like the Vesnin brothers, Moisei Ginzburg, and Ivan Leonidov. But Shpara's most vivid memory was of Le Corbusier, the congress's eminent foreign guest, who left an "enormous impression" on the auditorium by sketching live, in charcoal, a vision of modernist Paris on large sheets of paper tacked to 
the wall. ${ }^{39}$ Shpara also commented on the theoretical difficulty of that historical moment for Soviet designers, young and old. "Socialist city-building . . . proceeded under seriously difficult conditions, in an atmosphere of perpetual collision of various directions and ideas. A number of architects defended superurbanism-calling for the creation of giant cities with skyscrapers. Others, on the contrary, proposed to redistribute the population in separate complexes with one-story cottage-houses, located with gaps along transportation magistrals." ${ }^{40}$ Shpara's gloss of urbanist and disurbanist positions affirms that New Kharkiv head architect, Aleshin, was not the only designer at work on the sotsgorod well acquainted with contemporary design discourse in Moscow and beyond.

The New Kharkiv sotsgorod brief from February 1930, authored by the architectural team themselves, is a concise twenty-five-page instruction manual, filled only with information pertinent to design concerns. ${ }^{41}$ Aleshin later stated that the design team's charge was "not only to study the materials available at the end of 1929 and early 1930, but also to develop new facilities regarding the byt in all of its manifestations: housing, child-rearing, education, nutrition, exercise, medical care, recreation, etc. in architectural design terms." ${ }^{42}$ In line with this understanding, the architects' own brief is organized by building types: communal dining halls; childcare and educational facilities; zhilkombinat; "physical culture" and sports facilities; workers' clubs; food preparation facilities; mechanical laundries; and additional services (garages, shoe repair shops, etc.). Each of these categories is introduced with a short textual explanation of the general program, but the majority of the content is relayed in lists and charts that spell out the internal programmatic requirements for each type, their quantities, and areas. The structure of the New Kharkiv architects' brief mirrors the Magnitogorsk competition brief-it opens with information about demographics and territory then moves on to programmatic specifics-but it is exceedingly more detailed, as needed to generate constructible building types.

Armed with a clear set of instructions and target demographic numbers, the design team set feverishly to designing a standardized socialist urban model oriented to support the factory. The Giprograd design office's contract with Traktorstroi was signed on December 27, 1929. Draft designs of the sotsgorod and representative buildings of the residential sector were due March 1, 1930, working drawings for buildings in the residential sector were due April 20, and working drawings for the entire project were expected no more than sixty days later, on June $20 .{ }^{43}$ To move from contract to construction drawings in less than six months, for a city of 36,287 , was a design challenge of the highest order. Architectural standardization was a strategic imperative for the sotsgorod design team, just as it had been for the tractor factory design team.

The organization of the New Kharkiv brief suggests that the Giprograd design office was comprised of programmatically dedicated teams. Separated into small program-specific ateliers, the design groups could focus on a single new architectural type, whether a byt-transforming residential building, workers' club, live-in 
crèche, or factory kitchen. In January 1930, in his professorial role, Aleshin put out an open call to Kharkiv's third through fifth-year architecture students to assist with the New Kharkiv project. ${ }^{44}$ These students were joined soon after by Shpara and other recent architecture school graduates. ${ }^{45}$ Led by a limited number of seasoned designers, this small army of inexperienced but enthusiastic drafters cycled through numerous typological iterations.

While Shpara recalled the Kharkiv design effort with fondness, the stress imposed by the abbreviated timeline also comes through in his descriptions of that time:

The collective was industrious and friendly. We worked with ambition and fire (s pod"emom, sogon'kom), competing with one another. We paid no attention to time-it was all so new and interesting. Our supervisors were always nearby helping, making recommendations, supporting us. Thanks to them, and professor P. F. Aleshin in particular, the work was organized according to a regular rhythm. Despite the tight deadlines, we always provided the necessary construction documentation on schedule. The activities of our design bureau constituted not only a real school of creativity, but also a kind of scientific-research work, much of which was done for the first time. ${ }^{46}$

The youth and enthusiasm of the design team, as described by Shpara, certainly alleviated the pressure of tight deadlines, but even with dedicated type teams, and youthful energy to burn, the design schedule was near impossible. "Such a shockwork pace necessitated work not six-and-a-half hours a day, but often around the clock," Aleshin lamented after project completion. ${ }^{47}$

The divide and conquer typological method worked. According to Aleshin, the New Kharkiv design team met its obligations forty days before the contractual deadline, whereas the Traktorstroi factory design team did not. Despite having a construction-ready drawing set from which to work, the engineers at Traktorstroi were fifty-two days late in delivering their final draft of the factory design, a delay that caused coordination grief between the sostgorod and tractor factory projects. ${ }^{48}$ The sotsgorod design team intended to take its dimensional cues from the factory so that the standard and repeatable zhilkombinat blocks might rationally connect across the green zone to production entrances. The size of the residential buildings, the smallest planning unit, was also pegged to and dependent on the elusive factory layout. Nonetheless, the tractor factory site plan lingered. ${ }^{49}$

\section{Design of the Standardized Socialist City}

In an early sketch of a prototypical zhilkombinat drawn by Aleshin, a superblock holds two smaller blocks that are mirrored on the centerline of a circle; a solo block variant sits off to the side (figure 8.12). Architectural standardization is already 


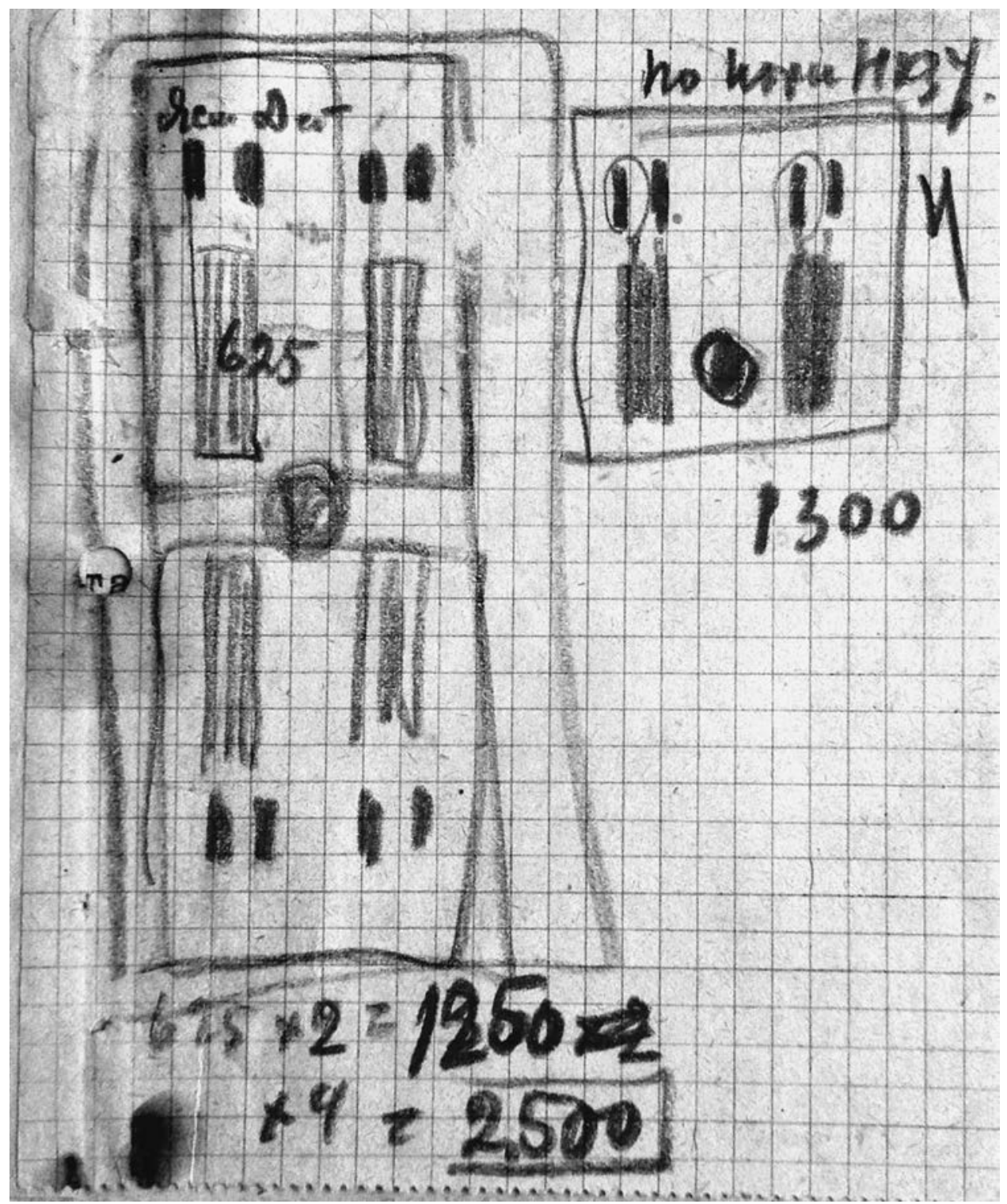

Figure 8.12. Zhilkombinat sketch for New Kharkiv, February 1930. Architects: Giprograd (Pavel Aleshin et al.). TsDAVO Ukrainy, f. 5, po. 3, od. zb. 2085, ark. 4.

evident in this first draft. Aleshin drew roughly the housing types (thin bars, each with a population of 625), school types (short nursery and kindergarten rectangles at the block edges), and a service building type (the circle) that would ultimately reach the project's demographic targets. Aleshin tallied accommodations at the building, block, and system level, to arrive at a total superblock population of 2,500. This was no arbitrary number. According to Shpara, the New Kharkiv zhilkombinat design "took into account the construction experience from the 
residential area at the Stalingrad Tractor Factory and the Magnitogorsk Metallurgic Plant, where analogous complexes were calculated to hold 2,500 people," though the constructed designs at New Kharkiv ultimately accommodated 2,730. ${ }^{50}$

An early rendered site plan shows the entire sotsgorod in a future build-out phase (figure 8.13). ${ }^{51}$ The linear plan is divided into three horizontal zones: heavy rail to the north with the lightly penciled factory just below; local transportation corridor and 500-meter green band; and the residential sotsgorod made from standardized zhilkombinat blocks that replicate insistently eastward in the promise of further colonization of the countryside. In this drawing, the factory precinct sets the block size: the factory zone's outside limits are carried down into the residential zone, and that total width is subdivided into six equal blocks. In the center of the six-block composition is a north-south road that leads directly to the factory's main gates; two minor block-dividing roads lead to minor factory entrances. There are just two prototypical zhilkombinat designs in use here, and they utilize the same few building types.

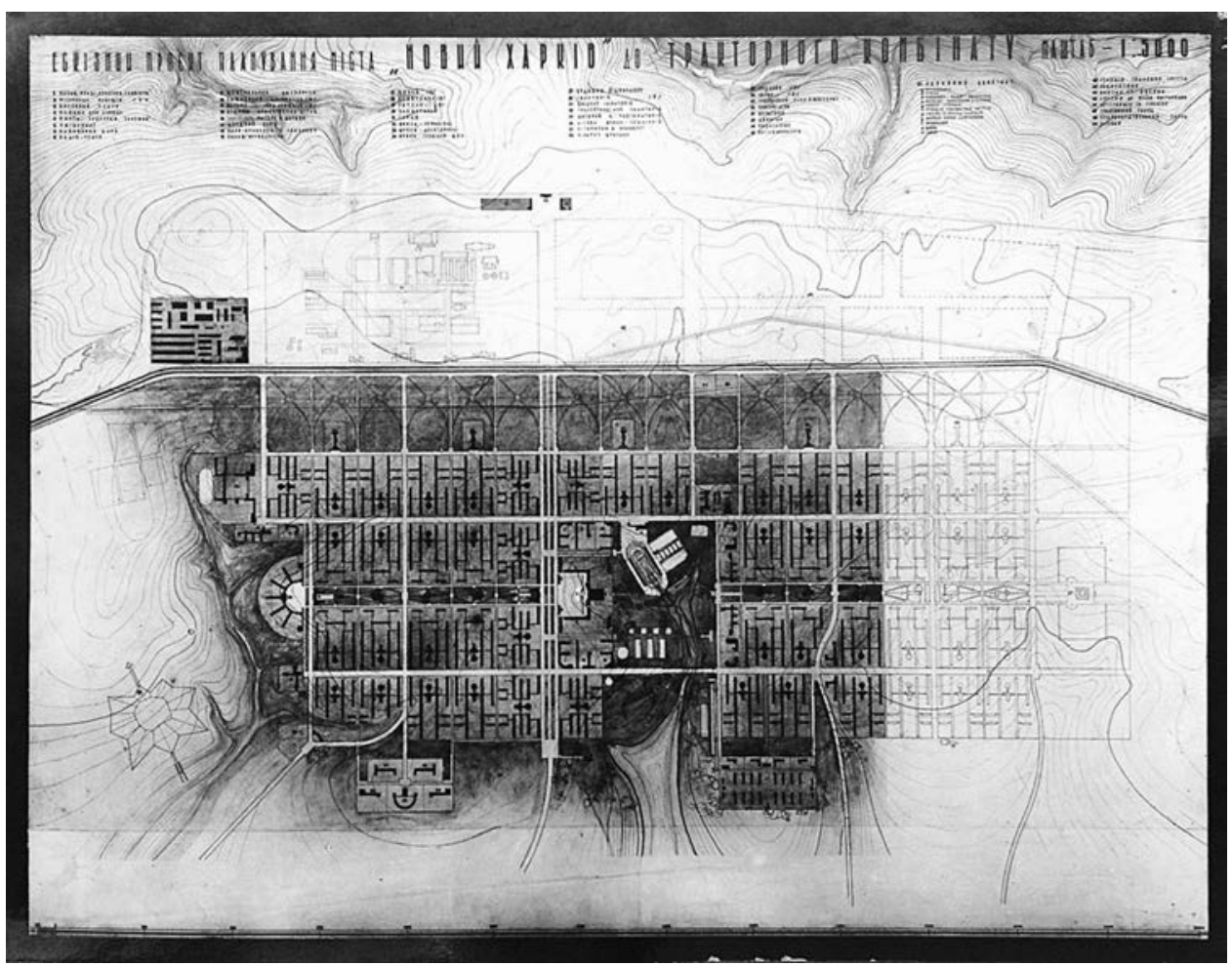

Figure 8.13. An early site plan, New Kharkiv sotsgorod, 1930. The linear plan is divided into three horizontal zones: heavy rail to the north with the factory just below; local transportation corridor and 500-meter green band; and the residential sotsgorod comprised of vertically rectangular repeated zhilkombinat blocks. Architects: Giprograd (Pavel Aleshin et al.). TsDAMLM Ukrainy, f. 8, po. 1, od. zb. 259 , ark. 38 . 
The most prevalent building type in the New Kharkiv sotsgorod is the apartment house. As socialist housing evolved from Baku through Magnitogorsk, the typical apartment house became ever thinner and taller, so that by Kharkiv the unadorned freestanding bar building appears to be a preordained solution. This thin housing bar still had typological competition from the traditional perimeter block at New Kharkiv, however, due to mercurial theoretical directives in early 1930. "The difficulties [of schedule]," Shpara noted, "were compounded by the fact that in the field of architectural theory there was still no consensus, the struggle did not abate." He continued:

Two generations of architects [at work on the sotsgorod design] were faced with the question of the planning structure of the new city. The older generation stayed on the side of the typical perimeter block structure with internal courtyards. We, the young generation, together with P.F. Aleshin, preferred the new type, the so-called line building (strochnaia zastroika), with the short ends of residential buildings facing the street, as the most appropriate to the conditions of socialist life. We put forth the following slogans: "Down with the old capitalist closed blocks! Give us linear buildings and through ventilation!" Of course, the new buildings were supposed to provide the most favorable lighting, maximum protection from noise, and surrounding green space. Sanitary doctors supported our position, and the project was built with linear buildings. ${ }^{52}$

According to Shpara, the health and hygiene argument that promoted buildings with maximum insolation, fresh air ventilation, and greenery won the day. Aleshin cited materials provided by Stroikom RSFSR and the Ukrainian NKVD in the New Kharkiv sotsgorod brief to set population, site coverage, and density rules to support mid-rise, freestanding housing types. He stated unequivocally that "new socialist cities should consist of a mixed generation population of 1,000-4,000 at a coverage of 20-25 percent and a density of 200-350 people per hectare. Once all of the facilities are installed to support the new socialist byt, and sanitary-technical and hygienic concerns addressed, it may be possible and desirable to increase density if the economic conditions allow." 53

A later site plan shows zhilkombinaty at a closer scale and is evidence of lingering coordination troubles between the factory and sotsgorod design teams (plate 21). The tractor factory is off the sheet to the north, but its final adjusted width seems to have forced recalculation of the zhilkombinat block size, since this first residential phase consists of five blocks, not six as previously rendered. Compositional laws of symmetry drive the plan at multiple scales. In this revised sotsgorod plan, a north-south axis of symmetry runs through the center block; to either side are the other two block types, mirrored about this center axis. The interior logic of each of the five zhilkombinat blocks is also symmetrical about an implied east-west 
mirror line. Symmetry plays a pragmatic role here as a tactic to wrest variety from a limited number of standardized block types. A symmetrically composed plan is largely agnostic about situational particularities. If the goal of the New Kharkiv design team was to create model urban blocks deployable in myriad situations, an implicitly logical symmetrical composition makes good sense.

As at Magnitogorsk, the New Kharkiv brief exhaustively articulates the required sociocultural buildings programmatically and dimensionally. Among the additional building types described is a residential nursery for children up to age three; residential kindergarten for children ages four to seven; residential school for youth ages eight to fourteen; workers' club with auditorium, buffet, meeting rooms, library, and chess room; physical recreation facilities for both summer and winter sport; cafeteria and factory kitchen; mechanical laundry; shoe repair shop; garage for 100 cars; storage for 150 bicycles and 50 motorcycles; vehicular repair shop; telephone station; and infirmary and dispensary. Particularly important is the physical culture and sports facility associated with each residential corpus, "in order that the residents are able to go to that space after waking up to do their calisthenics before going to work." ${ }^{54}$ The designs for the sotsgorod factory kitchen, built to provide 16,000 meals, the twenty-four-building hospital complex (with additional health amenities such as a running track), and a sizable cinema all demonstrate a notably Constructivist architectural aesthetic (plate 22). ${ }^{55}$ Although only a portion of the settlement-wide sociocultural infrastructure was constructed, photographs taken immediately after the first phase confirm that the clubs, canteens, and schools designed into the first zhilkombinat block were built from the start.

Specific building types, largely constructed as they were rendered, come into clearer focus in an evocative aerial perspective drawing of the first zhilkombinat block (one of the outermost blocks on the blueprint) (figure 8.14). Two narrow sixstory bars in the foreground hold dormitory-style living cells for singles. Six fourstory bars behind hold multiroom family units. In the middle of the composition sits a round-nosed workers' club attached at the back to a communal dining hall and mechanized laundry. Four identical educational buildings-elementary schools, kindergartens and nurseries - line the back of the block. The project brief stipulates that "all rooms in the residential sector must be connected between themselves and the premises of the socialized sector by warm corridors." ${ }_{56}$ These were included "so that children could walk to school without putting on outerwear, and could adults going to the store, canteen, or club." 57 The connecting skywalks are indicated on the blueprint by a single line to link the residential buildings and the social infrastructure together. In perspective, those lines become second floor glassed-in skyways sitting atop piloti (slim columns). The corridors' elevated position permits the ground plane to remain freely traversable between the residential bars.

The architects' creative aspirations are found in this aerial view. A three-propeller plane swoops into the upper right corner of the image to align the architectural project with its mechanized age. This drawing also highlights three architecturally 


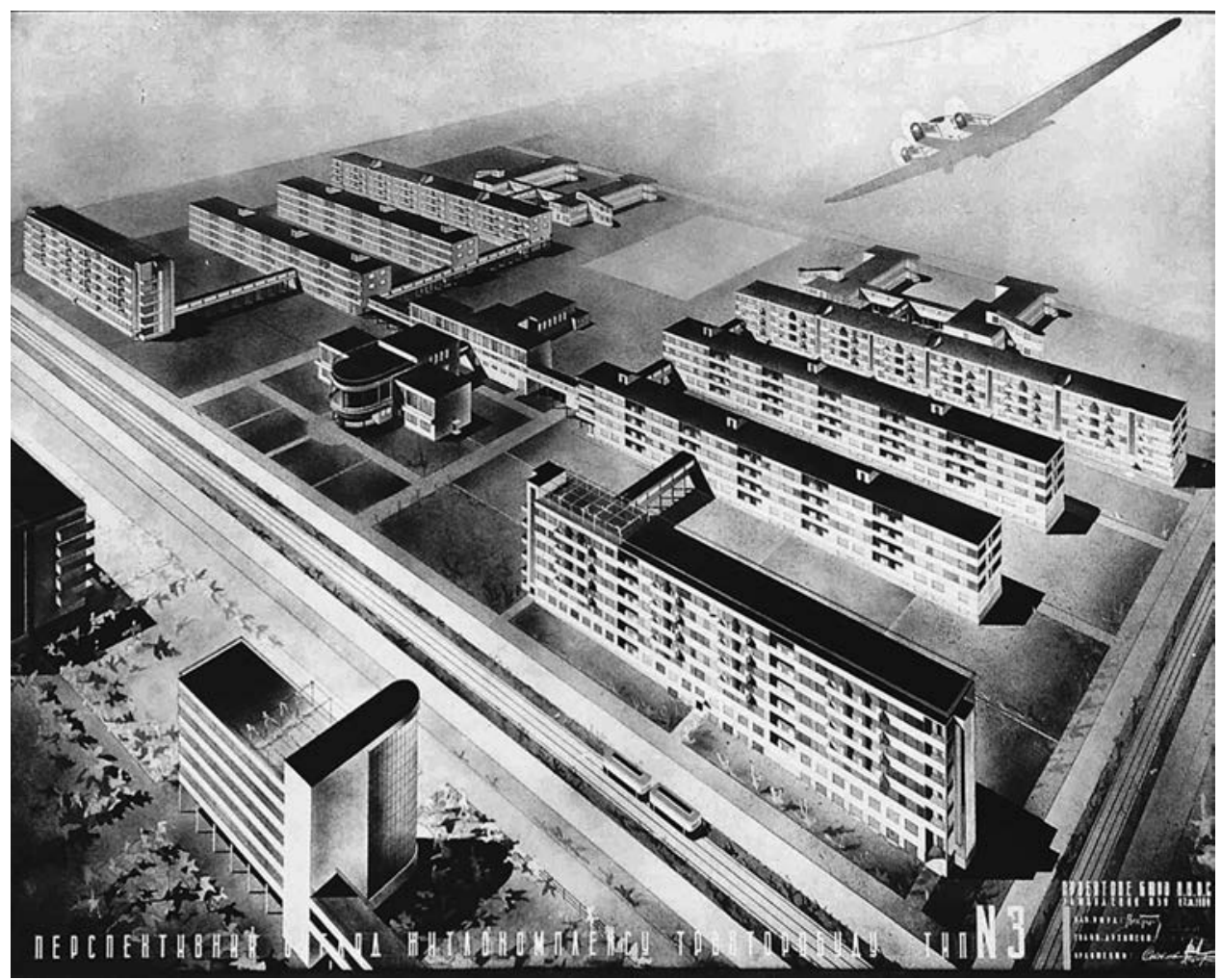

Figure 8.14. Bird's eye view of the first-phase zhilkombinat design, New Kharkiv sotsgorod, 1930. Architects: Giprograd (Pavel Aleshin et al.). TsDAMLM Ukrainy, f. 8, po. 1, od. zb. 259, ark. 389.

modernist details: flat roofs, narrow building widths, and broad functional facades. Each of these details, and the buildings' stripped aesthetic, align the New Kharkiv sotsgorod architecture not only with its Constructivist siblings in Moscow like the Narkomfin Building, but also New Frankfurt's zeilenbau (May's austere housing in Magnitogorsk had yet to be designed). The block reads as a perceptual whole due to consistent horizontal datum lines. Each story of each building is composed of a continuous opaque strip that conceals the floor slab and holds both the extended and inset balconies, alternating with a glazed strip of ribbon windows. Two additional zhilkombinat block prototypes, not rendered in the aerial but included on the blueprint, added a limited number of building types. In the first phase of construction seventy-eight buildings accommodating upwards of 7,500 residents were created from just ten building types. ${ }^{58}$

The most intimate architectural scale, the individual housing unit, was also designed for replication and for intense socialization. In a drawing of the single living cell (zhiliachik), the unit door opens onto a small foyer with a personal sink, then a second door leads into a narrow 2.86 meter (9.5-foot)-wide room with one generous window at the far end (figure 8.15). This unit was intended to enforce byt transformation of its occupant through economization (or elimination) of personal 
amenities. The architectural brief notes that "in the case where a unit is for one person, closets are not placed in the unit but in a convenient place so that one closet serves eight people, separated for men and women. Toilets for singles should be provided in common restrooms at a ratio of one toilet per fifteen people." ${ }^{59}$ Two shared bathrooms off the main corridor hold a bathtub and two toilets for common use. Despite the inconvenience of shared toileting and washing, the twelve square meters of personal space in the single units was a significant spatial improvement on the Union-wide standard of nine square meters per person. Common gathering space and a shared balcony occur periodically in each corridor. From the exterior, the six-story buildings register as repetitive cells relieved at regular intervals by the small-windowed bathrooms and balconied social spaces.

Most controversially the lender, Tsekombank, required these units to be kitchen-less as a trade-off for common dining facilities. This decision generated conflict between funders and architects on the one side, and eventual residents on the other. The All-Union Population Census of 1926 found that 36.5 percent of families shared a kitchen with others, 22.3 percent had no kitchen facilities at all, and 4 percent were unknown. ${ }^{60}$ Due to the acute housing crisis in the first decade of

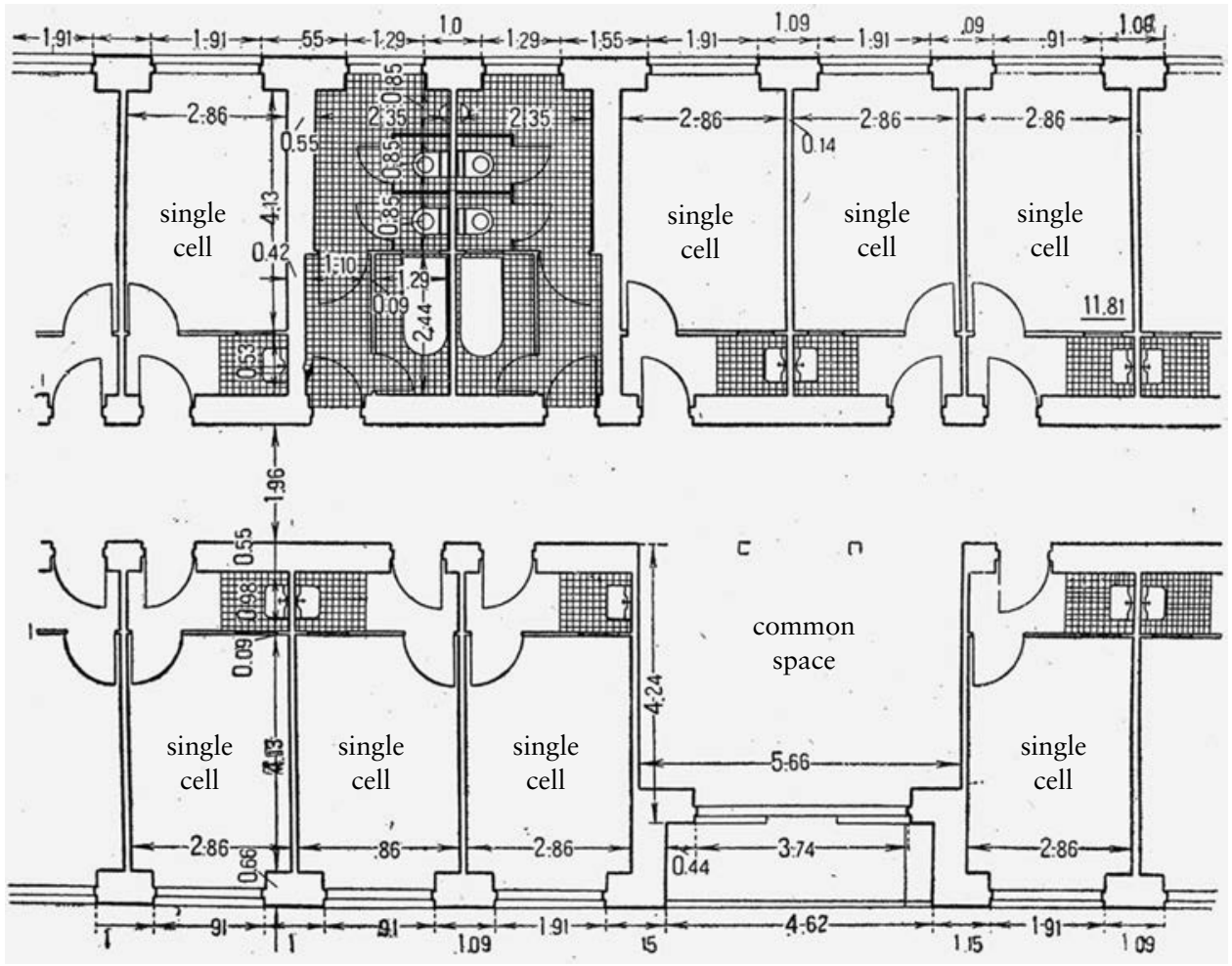

Figure 8.15. A plan for typical single living cells, New Kharkiv sotsgorod, Kharkiv, Ukraine, 1930. Architects: Giprograd (Pavel Aleshin et al.). Diagram by the author based on N. Baltuzevich, Opyt i uroki stroitel'stva KhTZ (Moscow: Gosstroiizdat, 1932), 23. 
Soviet power, half of the Soviet population already lacked a private kitchen. As chief of Moscow housing, Nikolai Popov, noted in 1925, excision of such a crucial amenity in the unit was fine for citizens amenable to sharing communal facilities, but the majority instead clamored "let us die in our [private] kitchens." ${ }^{61}$ To accommodate the transitional process of becoming fully socialist, Stroikom Typification Section units, like the Type F, provided small kitchen alcoves for reheating meals or making tea. ${ }^{62}$ But because of Tsekombank's stringent borrowing rules, the single living cells at New Kharkiv were designed without such alcoves, never mind a full kitchen. Local anecdotes claim that residents swiftly smuggled hotplates into these units to avoid having to rely solely on the zhilkombinat canteen. ${ }^{63}$

There is more unit variety among the family apartments in the four-story walk-up buildings (figure 8.16). A partial floor plan shows four units clustered around a single shared stairwell. The standard elements of these units include foyer, closet, washbasin, and toilet. A minimal "transitional" galley kitchen lines the main living space of each type. Of the four units in evidence, there is one one-room example, two two-room types, and a single three-room version. In this representative foursome, half of the units enjoy a balcony, all facing one side of the building.

The New Kharkiv project required that the architects work at multiple scales and with a high degree of innovation and improvisation to ensure that the architecture

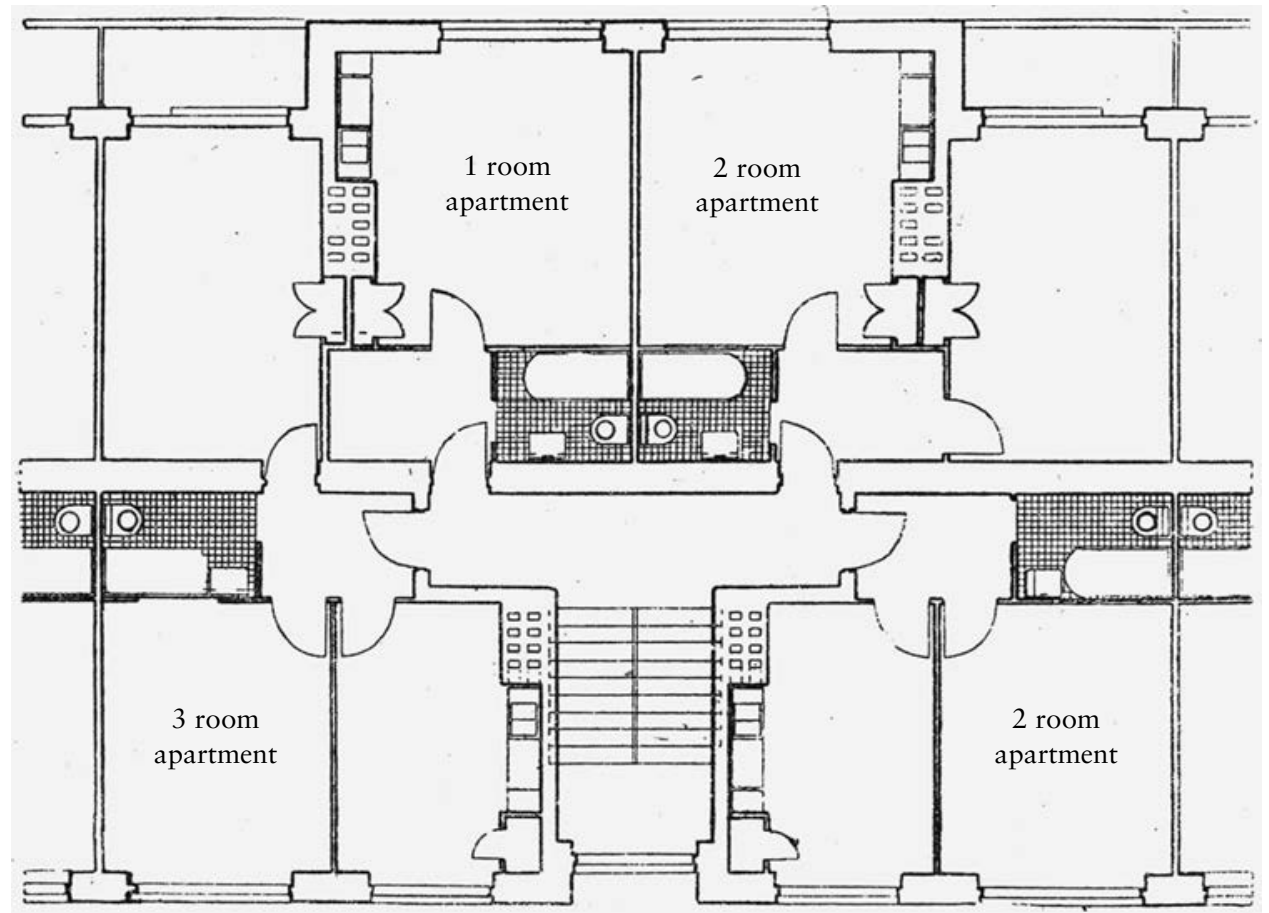

Figure 8.16. A plan for typical apartments in a house for families, New Kharkiv sotsgorod, Kharkiv, Ukraine, 1930. Architects: Giprograd (Pavel Aleshin et al.). Diagram by the author based on N. Baltuzevich, Opyt i uroki stroitel'stva KhTZ (Moscow: Gosstroiizdat, 1932), 24. 
met the charge to socialize its residents. It was a discomfiting assignment almost impossible to get right. Aleshin lamented after the project was finished that over and above conflicts between the factory and sotsgorod design teams, the turbulent intellectual environment was ultimately most damaging to both project schedule and cost. In a formal memo written after project completion, Aleshin discussed the toll taken on his team (Giprograd) by the abbreviated timeline for completion paired with fluctuating theoretical imperatives:

From the list of work completed by Giprograd on the tractor factory project, it should be evident that there was an extremely unclear sense of what the buildings should be, a lack of any material standards for designing the transitional [socialist] city and extremely diverse ideological positions in the various currents within Ukraine and all over the Union. Under these conditions, Giprograd engaged in a rather unexpected agreement not only to study the materials available at the end of 1929 and early 1930, but also to develop new facilities regarding the byt in all of its manifestations: housing, childrearing, education, nutrition, exercise, medical care, recreation, etc., in terms of architectural design.

Under shock-work construction conditions, Giprograd took full responsibility for the immediate fulfillment of its design obligations. Giprograd was forced to perform these tasks in the shortest possible time frame by going ahead of other similar construction projects, and without the benefit of other examples of sotsgorod construction.

Moreover, all of the well-known discussions about the ideological establishment of the transitional sotsgorod were taking place during the design process. There were also numerous commissions constantly questioning the creativity of our youth, the very workforce creating the architectural objects for Traktorstroi. All of these conditions unnerved the work and led to repeated adjustments and improvements on already-completed designs. This resulted in increased labor and costs.

For Giprograd, it was a great pleasure to read the decision by the TsK $\mathrm{VKP}(\mathrm{b})$ in the spring of 1930 on the left-wing distorter (levozagibshchikakh), Sabsovich. By that time Giprograd had already finished the Traktorstroi project, which corresponded to the party line.

This circumstance could only happen thanks to a deep exploration of the issues and through participation in discussions by professionals in Moscow, Kharkov, and Kiev. And through analysis by the whole Giprograd team of the conditions of construction and development for the transitional sotsgorod to reach the correct approach to solving the task. ${ }^{64}$

Aleshin claimed in his letter that there was no roadmap for the design work that Giprograd undertook at New Kharkiv. The terms for new architectural ensembles 
and objects-sotsgorod, zhilkombinat, zhiliachik-were coined but, as he noted, "there was an extremely unclear sense of what the buildings should be." What ensued was trial and error design "without the benefit of other examples of sotsgorod construction." Strictly speaking, this is true; no notably successful sotsgorod projects based on the sociospatial terms emerging from the debate had yet been built. To be conversant in the terms of the unfolding socialist urbanism debate, Aleshin and his team engaged in intense research. The vigorously annotated books on the debate in Aleshin's personal library testify to the architect's deep engagement with theoretical material, as do the copious and meticulously organized photographs of concurrent competition entries. He looked closely at the language and content of the Magnitogorsk brief and assessed the merits of the designs as he and his team crafted their own alternative. The Magnitogorsk competition brief acted, finally, as a true instaurational text for Aleshin and his Kharkiv team.

Because Aleshin became so well acquainted with the material from the socialist urbanism debate over such a short period of time-tracking the protagonists and their arguments, testing them against Giprograd's ongoing work to design a material environment-he was in a position to be critical of implausible recommendations. In what remains of Aleshin's personal library, there is only one Sabsovich book: City of the Future and Organization of Socialist Byt (Goroda budushchego $i$ organizatsiia sotsialisticheskogo byta, 1929). It is not well annotated. Aleshin's pleasure at reading the Central Committee's "Resolution on the work to restructure byt," that admonished Sabsovich by name, was undoubtedly due to his team's difficulty satisfying terms that attempted "in 'one jump' to clear those obstacles to the socialist reconstruction of byt." ${ }^{\circ 5}$ The theoretical ground was shifting, and yet for Aleshin and his team the deadlines were not.

Luckily for Giprograd, the New Kharkiv sotsgorod design was deemed a positive exemplar for future sites, in line with the new official position on socialist settlements. Ordzhonikidze, Politburo member and soon-to-be Commissar of Heavy Industry, reviewed the drawings for the project in 1931 and stated that New Kharkiv "fully meets the needs of the given period." 66

\section{Design Meets the Limits of Materials, Labor, and Force}

For the New Kharkiv sotsgorod designers, standardization meant devising a limited number of replicable options, a strategy that ran from the scale of the residential unit, to the building type, to the zhilkombinat block. Standardization permitted the timely completion of working drawings despite hand-wringing setbacks wrought by theoretical inconstancy. But, as had been the case with the tractor factory, once the sotsgorod design came into contact with the actual construction site, the carefully crafted system of standardized parts had to adjust. Two on-site conditions impacted 
the Giprograd designs most drastically: material availability and the skill level of the construction workforce.

The aerial perspective of the first zhilkombinat block, the architectural team's wish image, shows smooth white volumes horizontally striated with flush ribbon windows and recessed balconies running in the same band across the facades. Materiality is merely implicit in this drawing, but monolithic effect suggests either reinforced concrete construction or parged masonry. In reality, there was only one material option for the buildings on the New Kharkiv site, and that was brick. In the frantic preparation for construction, a brick factory capable of producing 40 million red bricks a year was built nearby. ${ }^{67}$ From the first through the subsequent construction phases, New Kharkiv was a brick complex.

The architects handled the material foisted on them with ingenuity. The narrow proportions of the housing were built as rendered, and from afar the signature horizontal striation also reads clearly (figure 8.17). Closer inspection reveals that the continuous ribbon window band is a trompe l'oeil (figure 8.18). The installed windows are not uninterrupted ribbon windows but are rectangular, mullioned, unmistakably punched openings that sit back from the building face to produce an undesirable shadow frame. The gridded effect of these openings is masked from afar with two simple additions: light-colored paint and finish tiles applied on top of the exterior brick. The dark bands that encircle the buildings are composed of windows, balconies, and dark bricks; the balance of the structure is painted or tiled in light yellow. The horizontally alternating result is, under the circumstances, in the same company as the rendered aspiration. The detail that most irrevocably divorces the rendering from the constructed condition, however, is the roof profile. All residential structures as built have traditional shallow-hipped roofs punctured by rows of chimneys that break aesthetic alliance with Constructivism. The shortage of steel on the tractor factory site, which caused significant material substitutions across the tracks, also affected the plans for the sotsgorod. The connecting heated skyways, reliant on long-span steel members, were left out of the initial construction phase, and they remained unbuilt in future phases.

New Kharkiv was a shock-work project not only for intellectual labor, as Aleshin claimed, but also for physical labor. Although some of the Stalingrad Tractor Factory leadership team and skilled workers were lured to continue at the Kharkiv project, the balance of the construction workforce was local, and the speed and simultaneity of tractor factory and sotsgorod construction impacted the allocation of that local workforce. Industrial construction was top priority, so skilled workers were pooled to complete the factory. A collection of barracks, like those seen at Magnitogorsk and Stalingrad, accommodated a small number of workers, but the site's relative proximity to Kharkiv meant that both construction and factory workers could commute from the city center or from local villages to the construction site in the short term. ${ }^{68}$ The majority arrived on the Losevo site daily after an hour-long tram or forty-minute bus ride from the city center. 


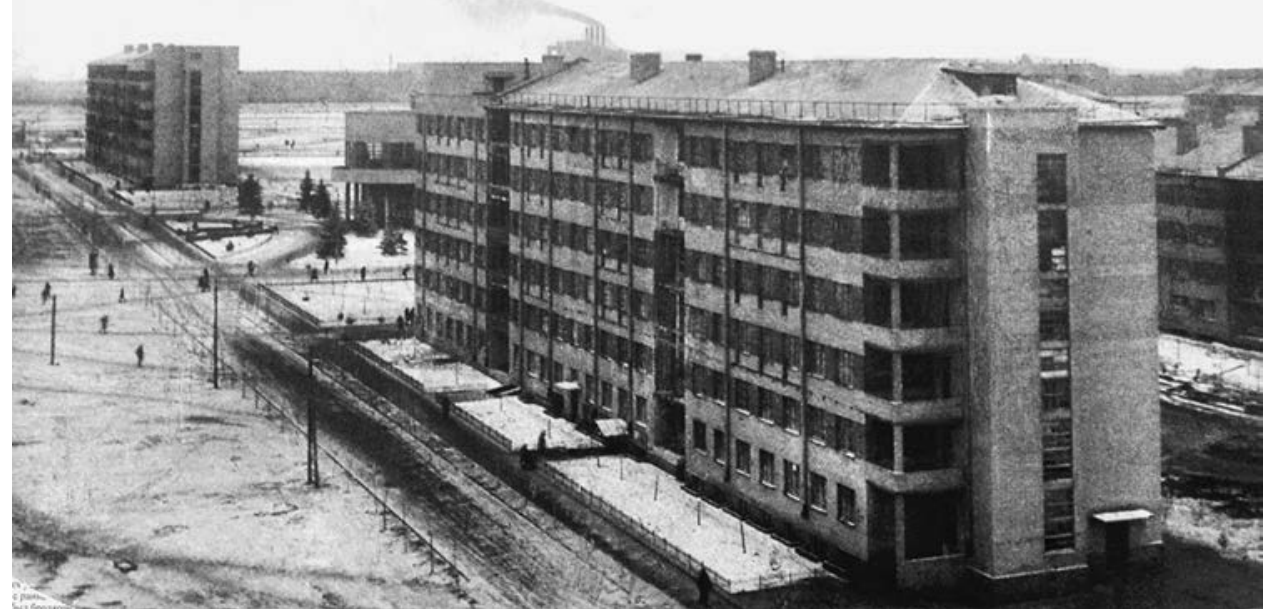

Figure 8.17. The first-phase zhilkombinat, with housing for singles in the foreground and the smokestacks of the factory in the distance, New Kharkiv sotsgorod, Kharkiv, Ukraine, c. 1932. Architects: Giprograd (Pavel Aleshin et al.). Derhzavna naukova arkitekturno-budivel'na biblioteka imeni V. G. Zabolotnogo.

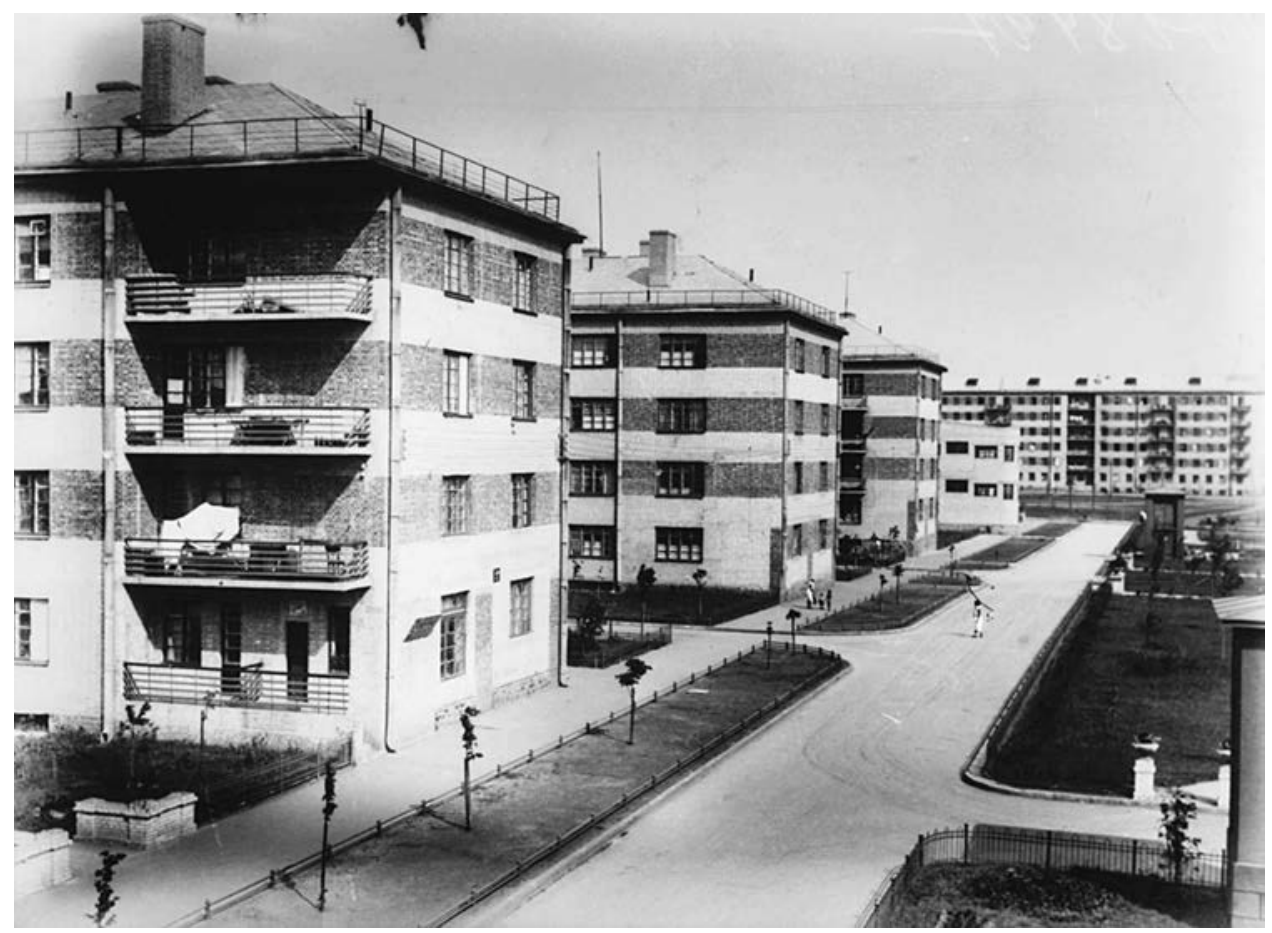

Figure 8.18. The first-phase zhilkombinat, with houses for families in the foreground, New Kharkiv sotsgorod, Kharkiv, Ukraine, c. 1932. Architects: Giprograd (Pavel Aleshin et al.). RGAKFD, 1-18947. 
According to accounts by Americans who lived at or visited the New Kharkiv site, a high percentage of construction work for the sotsgorod was completed by transient, unskilled, unpaid labor during subbotniki, or volunteer labor days. ${ }^{69}$ The US reporter Anna Louise Strong-an avowed communist who positively spun her Soviet accounts-visited the sotsgorod construction site in August 1931 and recounted her interactions with the largely volunteer workforce, including a husky black-haired Ukrainian digger of ditches and a band of girls carting away the dirt. She was told that "perhaps half of all the unskilled labor at Tractorstroi [sic], the digging and loading of dirt, the cleaning of the yards, etc., had been done by these volunteers. This may be an exaggeration," she noted, "it is hard to estimate the amount. But it is known to all that the works could not have been finished this year if it had depended on the labour available for hire, in the present labour shortage." Strong added that she could immediately spot the volunteers "by a certain festivity, as of workers not on a regular routine."70

Fred Beal was an American communist labor organizer who fled to the USSR in $1930 .{ }^{71}$ In 1931, he was sent to Kharkiv "to be in charge of propaganda and cultural relations, and serve as the contact man between the Soviet authorities and the foreigners." 72 In a Soviet-produced pamphlet, Beal reported much the same scene as Strong had. "As many as 17,000 workers shared in the construction of the plant. At least half of these workers came from the city of Kharkov and the surrounding small towns, giving their time voluntarily in what is called subbotniks," Beal explained. "One of the 'old timers' here told me that every morning a train and lorries loaded with workers came with bands playing and banners flying to do their share of work-usually unskilled, such as digging and loading dirt—-to help the new plant in operation in record time. The Red Army men also did their share of this heavy initial work." 73

Construction photographs show Red Army soldiers digging trenches, as Beal's excerpt notes (figure 8.19). They were not qualified to do much else on the site. The same held for the civilian volunteers who arrived "at half past six or seven" on a special train, according to Mrs. Raskin, one of the US housewives whom Strong interviewed. Like Beal, Raskin claimed that the volunteers came "with bands and banners; a different crowd each day, and always a jolly one." 74 The US engineer Leon Swajian, who oversaw the construction of the tractor factory, later also claimed collegiality and excitement in the volunteer workforce. "I don't think there was a man or woman in Kharkov who didn't come out to work on that plant," Swajian remembered. "Professors, women, girls, young bands of pioneers-they came every day in organized groups on 'subbotniki,' volunteering their free day to do unpaid work on their tractor plant. There were 400 to 500 of them every day, sometimes as many as 2,000. They came as if it was a good picnic. And why wasn't it? They wanted to see the big show and be in on it! Ten kilometers out from Kharkov they came, to where we were building not only the plant but the new workers' city." 75 


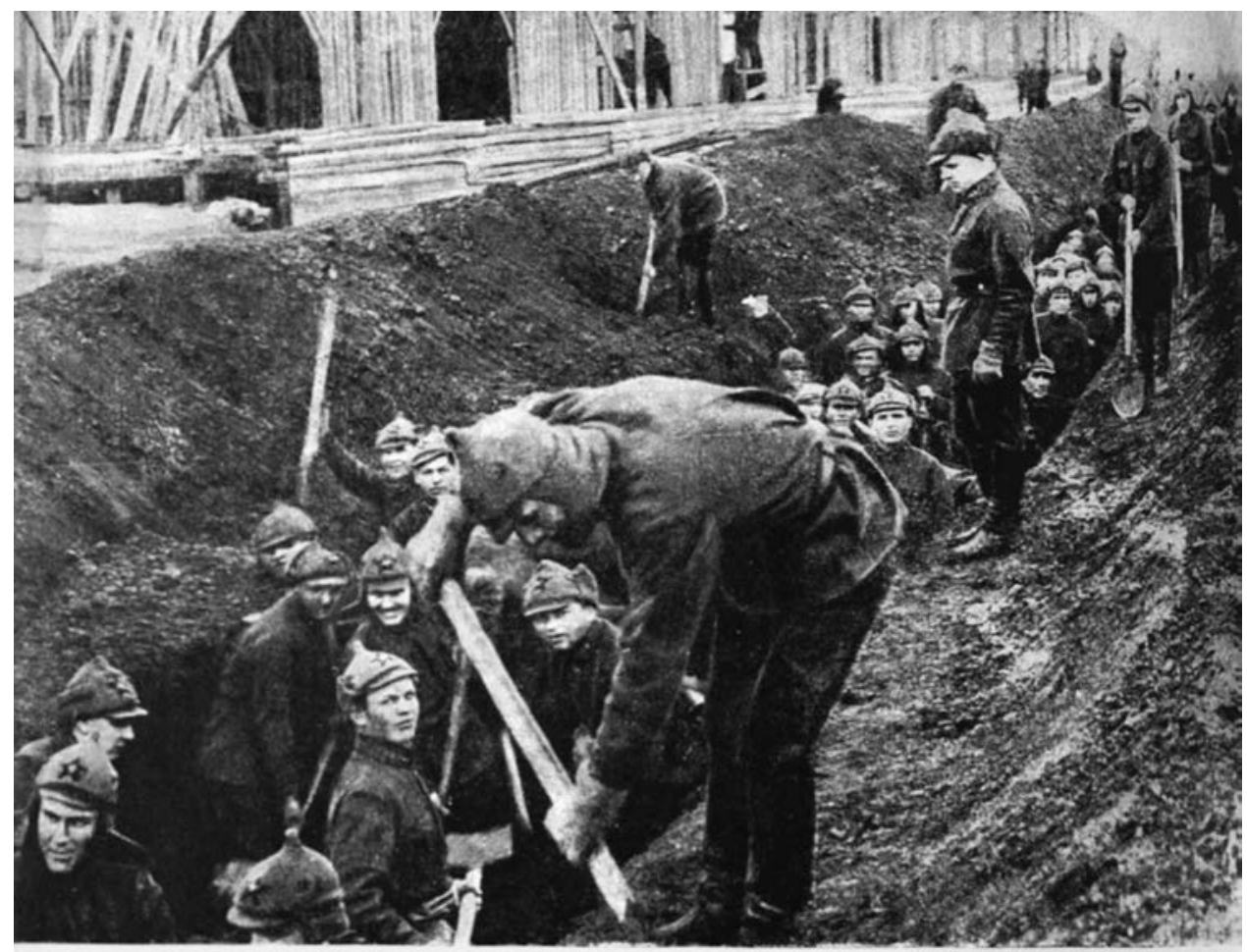

RED ARMY helps in construction

Figure 8.19. "Red Army helps in construction." Fred E. Beal, Foreign Workers in a Soviet Tractor Plant (Moscow: Co-operative Publishing Society of Foreign Workers in the USSR, 1933), 8.

Newsreel footage taken during construction provides a visual for this military and volunteer labor force on the New Kharkiv site (figure 8.20). ${ }^{76}$ The flickering film pans slowly over a snow-covered plain, rendered desolate by the high ratio of sky to land in the frame. ${ }^{77}$ This, the intertitles reveal, is the site designated for a Soviet tractor factory outside of Kharkiv, the new capital of Soviet Ukraine. In closer shots horses approach and pass the camera, drawing primitive carts loaded down with bricks and logs. The camera turns to an army of workers-shovels and ushanka earflaps flying - as they dig themselves deeper and deeper into the factory's foundation pit. Cut to black. The screen brightens once more on the plain-a steam train approaches. Young people standing in open doorways hop to the ground as a train slows in its passage across a barren landscape. They are there to "help speed construction" of the socialist city that will house tractor factory workers. A heavily scaffolded zhilkombinat building holds the background of the next shot in which three temporary workers stand, backs to the camera. The young woman in the center repeatedly turns her torso to the right, catches a brick, pivots, and slings it to the next volunteer in line to her left. Her body dips as the weight of each brick hits her hands. Extra hands would have been useful on simple tasks 

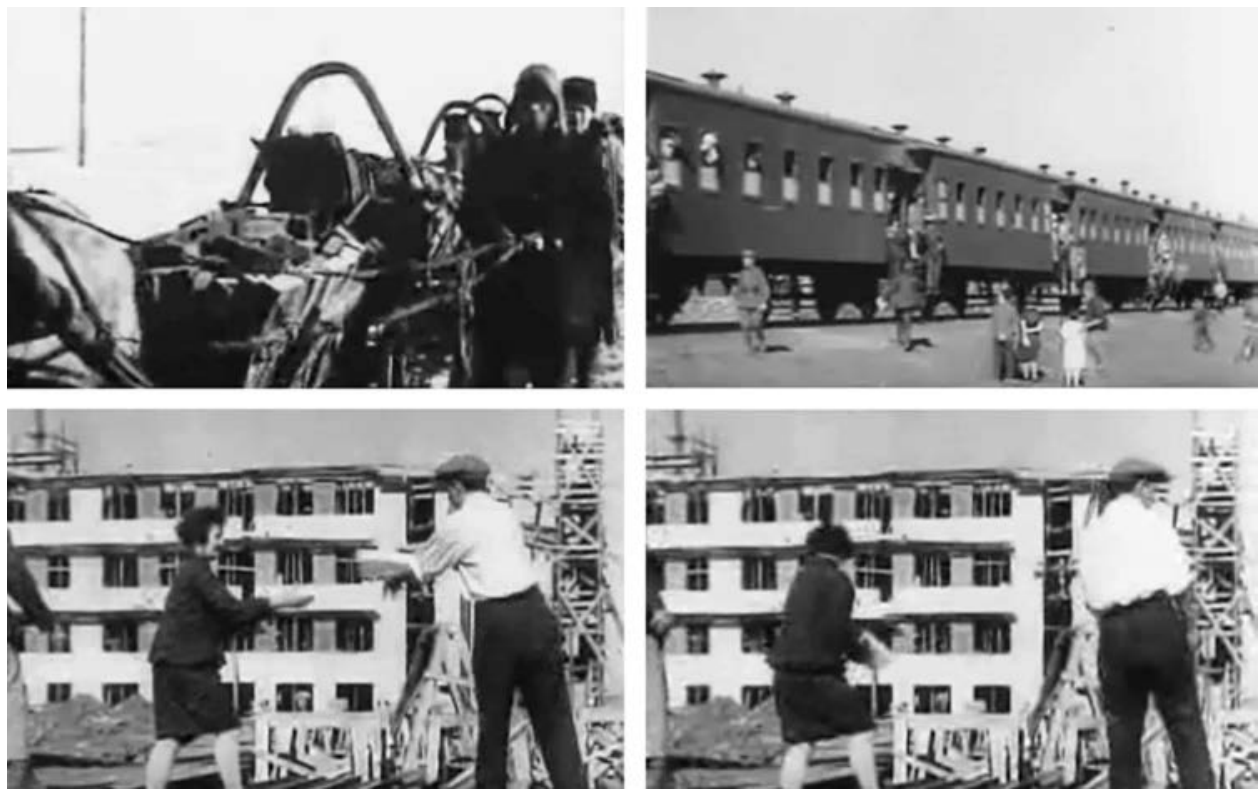

Figure 8.20. Construction newsreels from the Kharkiv Tractor Factory sotsgorod site, 1930. Materials brought to the site by horse cart (top left), worker "volunteers" arrive by train from the city (top right), worker "volunteers" sling bricks (bottom). TsDKFFA Ukrainy, od. obl. 1429, 1447, 1469, 1483, 1486, $1516,1517,1529$.

like moving bricks, or those that required brute force, like ditch digging. But organization of a job site staffed by transient unskilled workers was invariably a daily logistics challenge. Strong noted that each day New Kharkiv's chief of production faced the task of assigning jobs to yet another enthusiastic yet untrained group of volunteers.

Eve Garrette Grady, the wife of a US engineer at the tractor factory, questioned the picture of selfless volunteerism put forward by the above accounts, each released by a pro-Soviet media outlet. "Many times I have seen bookkeepers, clerks, stenographers, draftsmen-even professors from the University of Kharkov . . - men and women who work every day in the week in an office, a schoolroom, or a factory, briskly laying bricks at Tractorstroy on their free day. Refuse to go, they dared not. But those whom I knew used to smile ruefully, albeit quite furtively, as I passed and hold up their white, office-worker or scholar's hands, all torn and scarred and bleeding." 78

Whether the labor was volunteer or coerced (likely some combination thereof), the Kharkiv Tractor Factory was undoubtedly a site of local curiosity, removed from the established urban core and touted as one of Kharkiv's most significant contributions to the first Five-Year Plan. The sotsgorod was of particular interest. While there were many modern residential buildings constructed in Kharkiv city center during the late 1920s, New Kharkiv was the sole fully communalized complex. The 
sotsgorod was an important material touchstone for the new social order, one that even inner-city Kharkivites wished to have a hand in making, if not living in.

The largely unskilled workforce negatively affected the sostgorod project's quality of construction, however. Even if the architects had specified the most modern materials and processes, the composition of the labor pool on the construction site precluded complex assemblies. The US engineer Zara Witkin visited the tractor factory and sotsgorod in May 1932. By placing Kharkiv on his itinerary, Witkin noted that he had "one objective above all—the famous Kharkov Tractor Plant-and [I] insisted on seeing it, despite various objections which were raised." 79 After his visit, about a year after completion of the first zhilkombinat block, Witkin speculated why his guides sought to keep him away. "Near the factory a group of large apartment houses had been built to house the workers, engineers, foreign mechanics and consultants employed at the plant. We asked to see them," Witkin explained. "The recent rains had converted the dirt roads into mud, through which our car wallowed. This condition prevailed right up to the building. There had been no grading nor drainage around them. Mud and dirt had been tracked into the building. The staircases and walls were soiled. Though the houses had been 'completed' the previous year, rubbish and waste material remained in disorderly piles on the site." ${ }^{80}$ Witkin was new to the Soviet Union, and this was his first trip outside of Moscow. He saw Soviet construction with fresh eyes, which lends his description immediacy. But the American also was unaware of the difficult material and labor conditions that conspired to set the disorderly scene he saw before him (he would learn this firsthand over time). Given the rotating cast of temporary workers, who ultimately carried the responsibility to clean up the rubbish and waste materials on the construction site? Postoccupancy plans are not among the texts that survive in the archive.

A contemporary Soviet assessment of the first phase of sotsgorod construction noted that "the projects of Giprograd, more than any other of the types carried out in the tractor factory complex, were the objects of public and architectural discussion, and severe criticism, mainly by the production-workers on the construction, which resulted in a lot of defects that had to be rectified." ${ }^{81}$ Aleshin's Giprograd team was blamed for the so-called construction defects; however, it is more likely that the inexperienced workforce was the root of quality control problems.

Broadening the scope of inquiry beyond the immediate New Kharkiv design and construction project, to consider the sotsgorod's lived experience after move-in, and the context outside of the enclave, reveals a seriously distressing picture. In Proletarian Journey (1937), a memoir written after his escape from the Soviet Union, Fred Beal enumerated the complaints logged by the foreign workers under his purview, the members of the "privileged upper class, divided by a chasm from the ten thousand Russian workers employed [at the Kharkiv Tractor Factory]." 82 The foreigners' grievances included 50 percent longer work hours than paid for; lack of wood and coal for stoves and freezing residential conditions; high prices for clothes 
and shoes at the state store when (infrequently) available; and insufficient food. Beal reminded his US readers to place these complaints in context, however. "The large colony of privileged foreign workers at the Kharkov Tractor Plant subsisted on a starvation diet. How then shall I adequately describe the condition of the Russian workers? Did the Russian workers have the barest of necessities of life? Did they have warm clothes? Were the barracks in which they were quartered warm? Was the factory heated?" 83 These difficulties were tolerated by Soviet workers because outside of the high brick wall that surrounded the factory, each entrance of which was guarded by a soldier with a loaded rifle and fixed bayonet, was manufactured famine and genocide of the Ukrainian peasantry. ${ }^{84}$ Forced agricultural collectivization, directed from Moscow but undertaken by local actors, turned Kharkiv into a haunted city, overpopulated by peasants whose property was confiscated, and whose villages were subsumed in the now collective territory. They drifted into the center, hoping to secure food. Instead, many were rounded up by police and carted so far out of town that they could not return for exhaustion. ${ }^{85}$

Fred Beal devotes a chapter in his book to the enforced starvation that surrounded the tractor factory precinct. Because of the presence of armed guards, hungry peasants sought out other means of approaching better-provisioned workers on site. "Starving peasants and workers stormed the foreign colony at the Kharkov Tractor Plant every day," Beal explained. "With piteous cries for food, they went from house to house and from door to door whenever they could get past the guards stationed there. It was the only hope of getting bread. There was none on the land." 86 On a visit to a Ukrainian collective farm near the village of Chekhuyev in the spring of 1933, Beal and his companion saw "the worst of all possible sights." Only one live human remained, an old woman who spat at them as they approached. The rest of the collective had died of starvation. Their bodies, in various states of decomposition, were strewn throughout the village. ${ }^{87}$

The favorable outcome of New Kharkiv from an architecture and planning standpoint must be set against the horrific context in which it was created. From a systems perspective, the New Kharkiv sotsgorod project represents a successful installation of a replicable, and replicated, socialist urban block-the Armenikend superblock on a much larger scale-the benefits of which would be proven in time. Viewed in light of its local repercussions, the Kharkiv project suffers the taint of morally reprehensible political decisions made to install it. ${ }^{88}$ Were the architects responsible for the famine occurring in their midst? Of course not. But the project's very being was contingent on myriad acts of violence incurred to clear the way for its success.

The New Kharkiv sotsgorod was one of the first ground-up, explicitly socialist urban projects conceived, designed, and constructed in Soviet space. Linked together, the sotsgorod projects at Magnitogorsk and Kharkiv can be understood as stand-ins for theory and practice. Socialist city theory was generated for Magnitogorsk and implemented in Kharkiv. 
The architects for New Kharkiv did not have the benefit of a design development period before tackling the final version of the sotsgorod design. The shock-work tempo for completion meant that there would be no All-Union Design Competition for New Kharkiv. The project was simply assigned to a seasoned local architect who used both professional experience and research of prevailing trends to resolve the design problem as quickly as possible. Pavel Aleshin and his band of newly hatched Soviet-Ukrainian architects at Giprograd accomplished what Standartgorproekt, even under the seasoned leadership of Ernst May, could not. Namely, they created and installed a standardized unit of urban development, the replicable zhilkombinat, and provided a tested blueprint for future phases of build-out. Under much less scrutiny in Kharkiv than May suffered in Magnitogorsk, Aleshin was able to experiment in real time: drawing quickly, incorporating new theoretical precepts, and just building the thing. The first constructed zhilkombinat suffered from poor construction quality due to a host of material and labor factors, but architectural and planning standardization processes were launched that had an undeniable impact on subsequent settlements across Soviet territories.

By 1931, with a deeper collective understanding of large-scale planning issues, Giprogor (the State Institute for City Planning) began to work out the theoretical and methodological issues related to socialist settlement by applying the practice of architectural standardization to the problem of settlement types. ${ }^{89}$ In the late 1980s, an elderly Petr Shpara, recalling his time working on the Giprograd team for New Kharkiv, made the intellectual connection between the New Kharkiv zhilkombinat unit and the Khrushchev-era mikroraion (microdistrict). "Such complexes for 2,730 people to a large extent correspond to the modern groups of houses for 2,000-3,000 inhabitants, located in the mikroraion . . . The foundational architectural-planning decisions made then have stood the test of time and served as a reliable basis for further future development." 90 Soviet residential design tested in the early 1930s, and picked up again after Stalin's death, relied wholly on standardization. State planners' desire to replicate industrial concerns and residential quarters quickly across vast territories met success, finally, through the interscalar standardization of architectural details, standard building types, and predesigned settlement modules, like those devised for the New Kharkiv sotsgorod. 